\title{
Simulation Models on Human-Nature Interactions in Urban Landscapes: A Review Including Spatial Economics, System Dynamics, Cellular Automata and Agent-based Approaches
}

\author{
Dagmar Haase \\ Helmholtz Centre for Environmental Research - UFZ \\ Department of Computational Landscape Ecology, \\ Permoserstr 15, D-04318 Leipzig, Germany \\ email: dagmar.haase@ufz.de \\ http: //www . ufz $\cdot$ de/index $\cdot$ php?en $=4576$ \\ Nina Schwarz \\ Helmholtz Centre for Environmental Research - UFZ \\ Department of Computational Landscape Ecology, \\ Permoserstr 15, D-04318 Leipzig, Germany \\ email: nina.schwarz@ufz.de \\ http://www . uf $z$.de/index $\cdot$ php?en=13323
}

\section{Living Reviews in Landscape Research \\ ISSN 1863-7329}

Accepted on 2 April 2009

Published on 9 April 2009

\begin{abstract}
Urbanisation belongs to the most complex and dynamic processes of land use and landscape change. At present, we claim "the millennium of the cities," since more than half of the currently 6.6 billion world population is living in urban areas. Due to the huge impact of urban land consumption on environment and landscape, this paper provides a review of existing urban land use models. The review analyses non-spatially explicit economic and system dynamics models, spatially explicit cellular automata and agent-based model approaches by addressing the respective conceptual approach, model components and causal relationships, including feedbacks. Based upon the review, conclusions are drawn regarding the future development of urban landscape models, as well as on indispensable causal relationships and their representation when modelling urban systems.
\end{abstract}

Keywords: urban landscape, simulation models, land use change, review, system dynamics, cellular automata, agent-based model, feedback, causalities

This review is licensed under a Creative Commons Attribution-Non-Commercial-NoDerivs 3.0 Germany License. http://creativecommons.org/licenses/by-nc-nd/3.0/de/ 


\section{Imprint / Terms of Use}

Living Reviews in Landscape Research is a peer reviewed open access journal published by the Leibniz Centre for Agricultural Landscape Research (ZALF), Eberswalder Straße 84, 15374 Müncheberg, Germany. ISSN 1863-7329.

This review is licensed under a Creative Commons Attribution-Non-Commercial-NoDerivs 3.0 Germany License: http://creativecommons.org/licenses/by-nc-nd/3.0/de/

Because a Living Reviews article can evolve over time, we recommend to cite the article as follows:

Dagmar Haase and Nina Schwarz,

"Simulation Models on Human-Nature Interactions in Urban Landscapes: A Review Including Spatial Economics, System Dynamics, Cellular Automata and Agent-based Approaches",

Living Rev. Landscape Res., 3, (2009), 2. [Online Article]: cited [<date $>$ ], http://www.livingreviews.org/lrlr-2009-2

The date given as $<$ date $>$ then uniquely identifies the version of the article you are referring to.

\section{Article Revisions}

Living Reviews supports two different ways to keep its articles up-to-date:

Fast-track revision A fast-track revision provides the author with the opportunity to add short notices of current research results, trends and developments, or important publications to the article. A fast-track revision is refereed by the responsible subject editor. If an article has undergone a fast-track revision, a summary of changes will be listed here.

Major update A major update will include substantial changes and additions and is subject to full external refereeing. It is published with a new publication number.

For detailed documentation of an article's evolution, please refer always to the history document of the article's online version at http://www. livingreviews.org/lrlr-2009-2. 


\section{Contents}

1 Introduction $\quad \mathbf{5}$

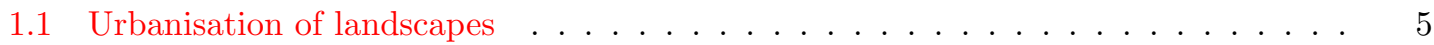

1.2 The "ideal" urban land use model . . . . . . . . . . . . . . . . . . . . . . . . . . . . .

1.3 Existing reviews on urban land use models . . . . . . . . . . . . . . . . . . . . . . 6

1.4 The purpose of this review . . . . . . . . . . . . . . . . . 7

2 Evaluating urban land use simulation models $r$

3 Models under review $r$

4 Representation of urban landscapes $\quad 14$

4.1 Spidergrams . . . . . . . . . . . . . . . . . . . . . 15

4.2 Relationships between human sphere and land use . . . . . . . . . . . . . . . . . 15

4.3 Impact of land use on environment . . . . . . . . . . . . . . . . . . . . . . 15

4.4 Feedback from environment to human sphere . . . . . . . . . . . . . . . . 18

4.5 Feedbacks between local and regional scale . . . . . . . . . . . . . . . . 18

5 Conclusions $r$

6 Acknowledgements 20

7 Annex $r$

$\begin{array}{ll}\text { References } & 40\end{array}$

\section{List of Tables}

Overview of main purposes and components investigated in reviewed models. . . . 11

2 Main components of urban systems - do the models under review include them? . 14

3 Household life cycle model for residential relocation behaviour [SE_1] . . . . . . . 21

4 Simulation of demographic changes and the housing market [SE_2] . . . . . . . . . 22

5 A System Dynamics Approach to Land Use / Transportation System Performance Modeling $\left[\mathrm{SD} \_2\right] \ldots \ldots \ldots \ldots \ldots \ldots \ldots \ldots$

6 CLUE-s (Conversion of Land Use and its Effects) [CA_1] . . . . . . . . . . . . . . . 24

7 CUF-2 (California Urban Futures) [CA_2] . . . . . . . . . . . . . . . . . 25

8 CURBA (California Urban and Biodiversity Analysis)(CA_3] . . . . . . . . . . . . 26

$9 \quad$ ILUMASS (Integrated Land-Use Modelling and Transportation System Simulation)

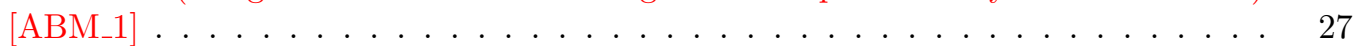

10 ILUTE (Integrated Land Use, Transportation, Environment model) [ABM_2] . . . 28

11 Modelling biodiversity and land use [SD_3] . . . . . . . . . . . . . . . . . . . . . . . . . . . . . . . . . . . .

12 MOLAND $\left[\mathrm{CA}_{-} 4\right] \ldots \ldots \ldots \ldots \ldots \ldots \ldots$

13 PUMA (Predicting Urbanisation with Multi-Agents) [ABM_3] . . . . . . . . . . 31

14 Rotterdam urban dynamics $[$ SD_4 $\ldots \ldots$. . . . . . . . . . . . . . . . . . 32

15 SCOPE (South Coast Outlook and Participation Experience) [SD_5] . . . . . . . . 33

16 Simulation of polycentric urban growth dynamics through agents [ABM_4] . . . . . 34

17 SLEUTH (Slope, Landuse, Exclusion, Urban Extend, Transportation and Hillshade)

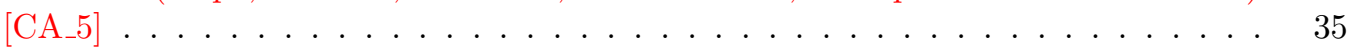

18 Urban dynamics $\left[\mathrm{SD}_{-} 1\right] \ldots \ldots \ldots \ldots \ldots \ldots$

19 Urban transformation process in the Haaglanden region [SD_6] . . . . . . . . . . . 37 
20 Urban travel system $\left[\mathrm{SD}_{-} 7\right] \ldots \ldots \ldots \ldots$

21 UrbanSim $[$ ABM 5$] \ldots \ldots \ldots \ldots$ 


\section{Introduction}

\section{$1.1 \quad$ Urbanisation of landscapes}

Urbanisation is one of the most complex and dynamic processes of landscape change. Although only about $4 \%$ of the world's land area is urbanised and densly populated (Ramankutty et al., 2006), we claim "the millennium of the cities," since more than half of the currently 6.6 billion world population is living in urban areas (United Nations, 2008, 2009; PRB, 2007; EEA, 2006; Kasanko et al., 2006). Projections for the future show that urbanisation - in terms of an increasing share of population living in urban areas - is very likely to continue (Batty et al., 2003; EEA, 2006; Lutz et al., 2001). Urbanisation is not only a societal problem, but also an environmental one, because it contradicts a normative ideal of "a natural or un-spoiled landscape" in spatial planning (Nuissl et al., 2008). In a multitude of studies it has been shown that land consumption is usually detrimental to the environment in different regards (e.g., Johnson, 2001; Antrop, 2004). Its impact reduces the ability of landscapes to fulfil human requirements and thus impairs ecosystem services and landscape functions in various ways (de Groot et al., 2002; Millennium Ecosystem Assessment, 2005; Curran and de Sherbinin, 2004). Individual ecosystem services and quality of life aspects that are affected by urbanisation include the production of food, the regulation of energy and matter flows, water supply, the provision of biodiversity and of health and recreation, and the supply of green space and natural aesthetic values (Alberti, 1999). Suburbanisation and urban sprawl were the dominating land consumption processes in North America and Europe after WW II (Batty, 2008). Recently, high growth rates in developing countries have led to enormous environmental loads as discussed above (Heinrichs and Kabisch, 2006). As urban systems are very densely populated and their land use components highly interlinked (Liu et al., 2007), developing views about their future is both a major concern in landscape research and a complex task. Modelling land use relationships helps to understand underlying drivers of land use change, to create future land use scenarios and assess possible environmental impacts (Lambin and Geist, 2006; Ravetz, 2000).

\subsection{The "ideal" urban land use model}

A variety of land use change models, particularly for urban landscapes, already exist, ranging from specific case studies to generic tools for a variety of urban regions. These models differ largely in terms of their structure, their representation of both space and human decisions, and their methodological implementation. Compared to land use change models in open landscapes, urban areas are shaped particularly by human activities, societal processes and human-nature interactions (Couclelis, 1997). In addition to implemented simulation models, a number of articles and book chapters elaborate on the "ideal" integrated model, theoretically necessary causal feedback loops etc. These "ideal" models shall serve as analytical frameworks to better understand the systems under study. Often, authors use frameworks like the DPSIR-framework (drivers, pressures, state, impact, responses) of the European Environment Agency (EEA) to conceptualise these conceptual models. According to Verburg, "the main drawback of using these analytical frameworks is the assumption of one-directional processes between driving factors and impacts" (Verburg, 2006, p. 1173), because in reality, it is difficult to differentiate between impacts and drivers in a system. Bürgi et al. (2004) distinguish five major types of driving forces: socioeconomic, political, technological, natural and cultural. Furthermore, they differentiate between primary, secondary and tertiary driving forces, as well as between intrinsic and extrinsic driving forces (Bürgi et al., 2004). In their introduction to urban simulation, Waddell and Ulfarsson (2004) sketched urban markets and agents, choices and interactions in an "ideal" urban land use model. Timmermans (2006) criticizes that present urban models focus on functional chains like the following: demand causes allocation across space, which in turn causes traffic flows, based upon which a transportation model calculates travel times, 
which in turn explain residential choice. Timmermans votes to include other aspects of integration in urban land use models, such as task allocation within households, residential choice, job choice, vehicle ownership, scheduling of activities, competition and agglomeration of land uses and actors, co-evolutionary development of demographics, employment sectors, land use and activity profiles and a more thorough treatment of varying time horizons, including anticipatory and reactive behaviour. According to Miller et al. (2004), an integrated urban systems model with a focus on transport should include socio-demographic components (evolution of population), demographics (demographic change and migration into and out of a region), decision-making (location choices of households and firms), economic variables (labour market, import/export of goods and services), transportation (activity and travel patterns of population, goods and services, depending upon urban structure and economic interchanges, performance of road and transit systems) and respective effects on land use (evolution of the built environment) and environment (atmospheric emissions generated by transportation and industry; Miller et al., 2004). Moreover, Hunt et al. (2005) stated eleven modelling axioms for such an "ideal urban land use model":

- Representation of an urban system should focus on those elements that interact with the transportation system.

- An urban system consists of physical elements, actors and processes.

- A transportation system is multimodal and involves both people and goods.

- Markets are the basic organising principle of an urban system.

- Flows of people, goods, information and money arise out of demand.

- Urban areas do not reach an equilibrium.

- System time must be explicitly dealt with.

- Feedback between short-term and long-term processes has to be integrated (e.g., travel and infrastructure).

- Some factors may be treated as exogenous for modelling purposes.

- Some activities arise in response to external demand.

- A very detailed level of representation for actors and processes is necessary.

\subsection{Existing reviews on urban land use models}

A variety of reviews including urban land use models already exist: Agarwal et al. (2002) as well as Schaldach and Priess (2008) review integrated land use models in general, also including models that deal with non-urban land uses such as forestry, pasture and agriculture. Axhausen (2006) specialises in models on transportation demand and traffic flows. Beckmann (2006) and Iacono et al. (2008) focus on interactions between urban land use and transportation. The authors predominantly discuss modelling approaches and does not give details regarding single models. Similar to this, Berling-Wolff and Wu (2004) provide an historical overview of modelling approaches and do not discuss single models. The U.S. EPA (2000) focuses on models of urban growth and sprawl but mainly includes U.S. American approaches and - because of its publication date does not include recently published models. Geurs and van Wee (2004) and Hunt et al. (2005) focus on models which emphasize the interaction between urban land use and the transportation system. Furthermore, Timmermans (2006) gives a historical overview and describes a large number of models but does not give a comparative description of presently developed models. With his

Living Reviews in Landscape Research

http://www. livingreviews.org/lrlr-2009-2 
review on modelling the urban ecosystem, Alberti (2008) puts less emphasis on urban land use change, but rather focues on the environmental impacts and human-induced environmental stress of the urban system. The review utilises a range of evaluation criteria, of which feedback mechanisms, multiple actors and the inclusion of uncertainy are seen as the most challenging (Alberti, 2008). Finally, Verburg et al. (2004) sketch a few exemplary models, but their focus lies on discussing general modelling approaches and not on single causal feedbacks.

\subsection{The purpose of this review}

Set against the background summarised in Section 1.3, this review analyses economic models, system dynamics approaches, cellular automata and agent-based models developed for urban systems by systematically addressing a range of critieria such as the conceptual approach, model components and included variables. In doing so, it aims at giving an overview on the respective model structures. The main purpose of the review is to derive ideas for causal relationships within land use change in urban systems, with a special emphasis on integrating social and natural science dimensions. The innovative aspect of this review compared to existing reviews is the aim to explicitly analyse causalities and feedbacks in urban land use changes.

As Verburg (2006) points out, an integration of social and biophysical systems could be enhanced by including feedback mechanisms in land use models, e.g., the feedback between driving factors and effects of land use change (here understood as impacts), the feedback between local and regional processes, and the feedback between agents and spatial units (Verburg, 2006). "Less common in land use modelling is the simulation of feedbacks between impacts on socio-economic and environmental conditions and the driving factors of land use change" (Verburg, 2006, p. 1173). Therefore, the review presented here will include a glance at those feedbacks. Since urban land use models deal with spatial entities - that is, among others, the landscape itself - an important aspect of selecting modelling approaches for the review is spatial explicitness in terms of landscape property. In addition, urban landscapes are highly complex, as highlighted in several paragraphs of the introduction part of this paper; therefore, one should focus on comprehensive models that include different relationships, influences and dependencies along with their spatial representation. The paper is organised as follows. Section 2 sets up a set of evaluation criteria for conducting the model review, which follows in Section 3. Section 4 especially focuses on causalities and feedback loops of land use change, before coming to the paper's conclusions (Section 5). 


\section{Evaluating urban land use simulation models}

Compared to natural or agricultural landscapes, urban systems are strongly influenced by both the social and the natural dimension. As mentioned in the introduction, urban landscapes are coupled with human-nature systems (Liu et al., 2007), with many interlinkages between the human sphere - first and foremost demography and economy - land use and the environment. Figure 1 provides a very general but comprehensive overview on the major components of an urban landscape: the major driving force for change is the human sphere, which creates pressures on the state of the land use, which again will have effects on the environment, its natural resources and ecosystems.

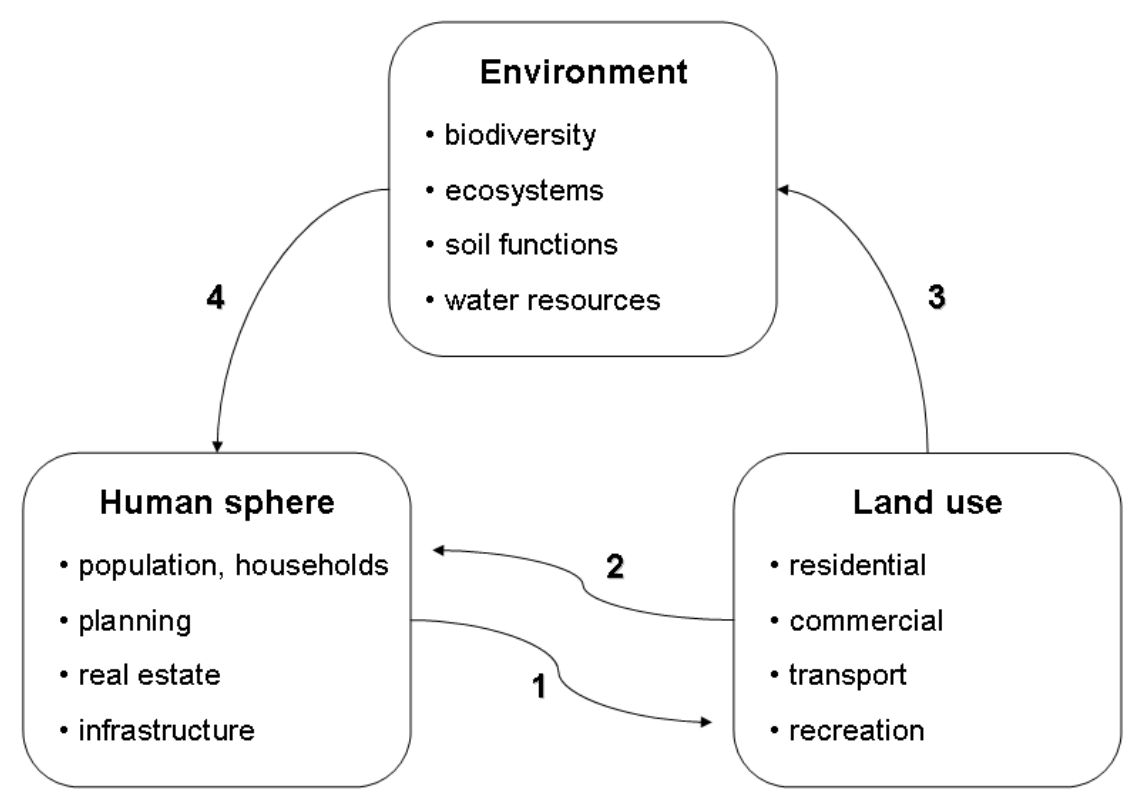

Figure 1: Main components (human sphere, land use, natural resources) and relationships (1-4) which describe human-nature interactions in urban regions: (1) Impact of human sphere on land use, (2) feedback of land use on human sphere, (3) impact of land use on environment (including ecosystems) and (4) feedback of environment on human sphere.

The human sphere characterises the socio-economic system of cities: it comprises variables such as population (development), households, spatial planning and governance, the real estate market, commercial activities and infrastructure, including transportation. Specifically, the human sphere includes human decision making and actions upon land use. The land use component itself comprehends all types of typical urban land uses such as residential, industrial, commercial, transport and recreation. The third component contains natural resources, such as ecosystems, biodiversity, soil functions and water resouces (cf. again Figure 1). We set up these feedback loops between the three dimensions/components of the urban system discussed above: (1) the impact of the human sphere on land use, (2) the feedback (= reverse to the impact function) of land use on the human sphere, (3) the impact of land use on the environment and (4) another feedback of the environment on the human sphere. All relationships are labelled in Figure 1, respectively. Furthermore, a short Section (4.4) deals with the scale-specific causal feedbacks between local and regional scale, insofar as they are covered by the models investigated. The evaluation of the feedback loops includes (1) the identification of a respective formal representation of the respective

Living Reviews in Landscape Research

http://www.livingreviews.org/lrlr-2009-2 
causalities in the model and (2) whether or not they have an impact on other model components again/vice versa. In order to structure the review and to give brief overviews of the models under review, we summarised the findings of the analysis of each of the models in Table 1, which provides comprehensive information about the main purpose and major components classified according to Figure 1. 


\section{Models under review}

With respect to the model evaluation criteria mentioned in previous reviews and for the "ideal urban model" (Sections 1.2 and 1.3), we solely focus on causalities and feedback loops in the models under review, as we believe that alongside a good description of model components (human sphere, land use, environment), representation of the linkages between the components (= impacts and feedback loops) make up the comprehensiveness and the explanatory strength of the models. The models included in this review were selected in order to represent the most influential streams of urban land use change modelling. First, the review includes models well known within the community, such as those which are discussed in the related literature on urban land use change, e.g., by being referenced in other reviews. Second, system and land use approaches which are not discussed at great length in the literature were included, because system dynamics as a method forces modellers to think in a systemic way and easily allows for the inclusion of feedback mechanisms. For system-oriented, causality-driven models on at least one dimension of urban land-use change, a search on the ISI Web of Science was performed. This procedure led to a total of 19 models, which were also included in this review. These models are listed in the form of a comprehensive overview in Table 1. Details are given in the Annex 7.

Roughly four different modelling approaches can be distinguished. Two of the models under review belong to the class of spatial economics/econometric models (SE_1 and SE_2: Nijkamp et al., 1993; Mankiw and Weil, 1989). These models mainly look at demography and household-driven demand-supply relations in urban regions, such as housing market developments. Seven models included in this review (SD_1 to SD_7: Forrester, 1969; Haghani et al., 2003a,b; Eppink et al., 2004; Sanders and Sanders, 2004; Onsted, 2002; Eskinasi and Rouwette, 2004; Raux, 2003) are system dynamics or causality-driven models (Table 1). System dynamics is an approach which models complex systems using stocks and flows and by explicitly including feedback loops in the model (Sterman, 2000). System dynamics models are - in their standard application - not spatially explicit. Rather, the structure of combining stocks, flows and feedback mechanisms leads to a set of differential equations. The outcome of these equations can be simulated, given values for parameters and initial conditions. The classical approach to modelling urban systems using system dynamics is Forrester's book on "Urban Dynamics" (Forrester, 1969): He linked the three subsystems "business," "housing" and "population" to describe and model urban systems in general, subsequently differentiating each of the three subsystems in very detailed sub-models. Five models included in this review (CA_1 to CA_5: Verburg and Overmars, 2007; Landis and Zhang, 1998a,b; Landis et al., 1998; Engelen et al., 2007; Dietzel and Clarke, 2007) use cellular automata as the main modelling technique (Table 1). A cellular automaton consists of an n-dimensional grid of cells. Each cell has a finite number of states. Cells change their state simultaneously according to the same rules coded in the model, and the state of a cell in time $t$ solely depends on the state of neighbouring cells in $t_{-1}$ (cf. Clarke et al., 1997; Landis and Zhang, 1998a,b; Silva and Clarke, 2002). Land use change models use cellular automata with 2-dimensional grids which represent the majority of land use. Each cell symbolises a patch of land, and states of cells are the land use options. Five models in this review (ABM_1 to ABM_5: Strauch et al., 2003; Salvini and Miller, 2005; Ettema et al., 2007; Loibl et al., 2007; Waddell et al., 2003) use agent-based approaches as the main modelling technique (Table 1). Agent-based models consist of autonomous individuals (agents) who perceive their environment and interact with one another (Parker et al., 2003). Applications of agent-based modelling in land use change are usually spatially explicit, and agents represent, for example, households relocating their homes or individuals using transport systems, but also governmental and other institutional bodies.

Living Reviews in Landscape Research

http://www. livingreviews . org/lrlr-2009-2 
Table 1: Overview of main purposes and components (according to Figure 1) investigated in reviewed models.

\begin{tabular}{|c|c|c|c|}
\hline Model & Main purpose & Components & Reference \\
\hline \multicolumn{4}{|c|}{ Spatial Economics / Econometric models } \\
\hline SE_1 & $\begin{array}{l}\text { Modelling household life cycles } \\
\text { and their impact on residential re- } \\
\text { location behaviour and the urban } \\
\text { housing market for a European } \\
\text { capital city. }\end{array}$ & $\begin{array}{l}\text { Human sphere (population, migra- } \\
\text { tion, household, transportation, } \\
\text { housing market, prices, dwellings, } \\
\text { vacancies) }\end{array}$ & $\begin{array}{l}\text { Nijkamp et al. } \\
(1993)\end{array}$ \\
\hline SE_2 & $\begin{array}{l}\text { Simulation of demographic } \\
\text { changes (baby boom and baby } \\
\text { bust) and its influences on the } \\
\text { housing market in the U.S. }\end{array}$ & $\begin{array}{l}\text { Human sphere (population, migra- } \\
\text { tion, household, housing market, } \\
\text { prices, dwellings, vacancies) }\end{array}$ & $\begin{array}{l}\text { Mankiw and } \\
\text { Weil (1989) }\end{array}$ \\
\hline \multicolumn{4}{|c|}{ System Dynamics } \\
\hline SD_1 & $\begin{array}{l}\text { Modelling urban system in gen- } \\
\text { eral, explicitly including "urban } \\
\text { decline." Examples: focus on a } \\
\text { specific topic, e.g., rapid popula- } \\
\text { tion growth, demolition, et cetera } \\
\text { and therefore need specific models. }\end{array}$ & $\begin{array}{l}\text { Human sphere (business, housing, } \\
\text { population) }\end{array}$ & $\begin{array}{l}\text { Forrester } \\
(1969) ; \text { Alfeld } \\
(1995)\end{array}$ \\
\hline SD_2 & $\begin{array}{l}\text { Integrated land-use and trans- } \\
\text { portation model for estimating } \\
\text { scenarios regarding transport poli- } \\
\text { cies }\end{array}$ & $\begin{array}{l}\text { Human sphere (population, mi- } \\
\text { gration, household, job growth, } \\
\text { employment and commercial land } \\
\text { development, housing develop- } \\
\text { ment, travel demand, congestion) }\end{array}$ & $\begin{array}{l}\text { Haghani et al. } \\
(2003 \mathrm{a}, \mathrm{b})\end{array}$ \\
\hline SD_3 & $\begin{array}{l}\text { Assessing the impact of urban } \\
\text { sprawl on wetland biodiversity } \\
\text { and social welfare }\end{array}$ & $\begin{array}{l}\text { Human sphere (population) } \\
\text { Land use (agricultural land, wet- } \\
\text { lands) } \\
\text { Environment (wetlands, nature } \\
\text { protection) }\end{array}$ & $\begin{array}{l}\text { Eppink et al. } \\
(2004)\end{array}$ \\
\hline SD_4 & $\begin{array}{l}\text { Redefining the model of urban } \\
\text { dynamics by Forrester (1969), in- } \\
\text { cluding: } 1 . \text { spatial dimension ( } 16 \\
\text { squares) and } 2 . \text { disaggregation: } \\
\text { different types of housing, indus- } \\
\text { try, and people in zones }\end{array}$ & $\begin{array}{l}\text { Human sphere (population, hous- } \\
\text { ing availability, houses, land avail- } \\
\text { ability, business structures, and } \\
\text { job availability, labour market and } \\
\text { housing market) }\end{array}$ & $\begin{array}{l}\text { Sanders and } \\
\text { Sanders (2004) }\end{array}$ \\
\hline SD_5 & $\begin{array}{l}\text { Simulation model to provide sce- } \\
\text { narios for future land use in Santa } \\
\text { Barbara, e.g., with restrictions to } \\
\text { urban growth }\end{array}$ & $\begin{array}{l}\text { Human sphere (housing, popula- } \\
\text { tion, business) } \\
\text { Land use } \\
\text { Quality of life }\end{array}$ & Onsted (2002) \\
\hline SD_6 & $\begin{array}{l}\text { Assessing the impact of future } \\
\text { policy interventions on the social } \\
\text { housing market (specific: rate of } \\
\text { building new dwellings) }\end{array}$ & $\begin{array}{l}\text { Human sphere (commercial hous- } \\
\text { ing stock, social housing stock, } \\
\text { waiting families, supply of avail- } \\
\text { able social houses; migration, de- } \\
\text { molition, construction) }\end{array}$ & $\begin{array}{l}\text { Eskinasi and } \\
\text { Rouwette } \\
(2004)\end{array}$ \\
\hline
\end{tabular}


Table 1 - Continued

\begin{tabular}{|c|c|c|c|}
\hline Model & Main purpose & Components & Reference \\
\hline SD_7 & $\begin{array}{l}\text { Simulating medium- and long-term } \\
\text { effects of urban transportation } \\
\text { policies with reference to sustain- } \\
\text { able travel }\end{array}$ & $\begin{array}{l}\text { Human sphere (urbanisation, in- } \\
\text { ternal travel demand, car own- } \\
\text { ership, external travel demand, } \\
\text { transportation, socio-economic } \\
\text { evaluation) } \\
\text { Environment (environmental ap- } \\
\text { praisals) }\end{array}$ & Raux (2003) \\
\hline \multicolumn{4}{|c|}{ Cellular Automata } \\
\hline CA_1 & $\begin{array}{l}\text { Tool for understanding land-use } \\
\text { patterns, possible future scenarios } \\
\text { for given demand }\end{array}$ & $\begin{array}{l}\text { Human sphere (demand rules) } \\
\text { Land use (suitability rules) }\end{array}$ & $\begin{array}{l}\text { Verburg and } \\
\text { Overmars } \\
(2007)\end{array}$ \\
\hline CA_2 & $\begin{array}{l}\text { Simulating urban growth, scenar- } \\
\text { ios for future development }\end{array}$ & $\begin{array}{l}\text { Human sphere (population, house- } \\
\text { hold, jobs, employment) } \\
\text { Land use (single-family residential, } \\
\text { multi-family residential, commer- } \\
\text { cial, industrial, transportation, } \\
\text { public) } \\
\text { Environment (undeveloped land) }\end{array}$ & $\begin{array}{l}\text { Landis } \\
\text { and Zhang } \\
(1998 \mathrm{a}, \mathrm{b})\end{array}$ \\
\hline CA_3 & $\begin{array}{l}\text { Development of policy scenarios of } \\
\text { urban growth, impact on habitat } \\
\text { change/biodiversity }\end{array}$ & $\begin{array}{l}\text { Human sphere (urban growth, } \\
\text { policy simulation and evaluation) } \\
\text { Environment (habitat change and } \\
\text { habitat fragmentation) }\end{array}$ & $\begin{array}{l}\text { Landis et al. } \\
(1998)\end{array}$ \\
\hline CA_4 & $\begin{array}{l}\text { Monitoring developments of urban } \\
\text { areas and identifyng trends at the } \\
\text { European level, focus is on growth } \\
\text { scenarios }\end{array}$ & $\begin{array}{l}\text { Human sphere (population, econ- } \\
\text { omy, planning, accessibility via } \\
\text { transportation network) } \\
\text { Land use (land use functions) }\end{array}$ & $\begin{array}{l}\text { Engelen et al. } \\
(2007)\end{array}$ \\
\hline CA_5 & $\begin{array}{l}\text { Modelling urban growth, scenar- } \\
\text { ios for future development of an } \\
\text { urban region }\end{array}$ & $\begin{array}{l}\text { Land use (urban or non urban, } \\
\text { roads, different land use types) } \\
\text { Environment (topography) }\end{array}$ & $\begin{array}{l}\text { Silva and } \\
\text { Clarke (2002); } \\
\text { Dietzel and } \\
\text { Clarke (2007) }\end{array}$ \\
\hline \multicolumn{4}{|c|}{ Agent-Based Models } \\
\hline ABM_1 & $\begin{array}{l}\text { Dynamic simulation model with } \\
\text { a focus on urban traffic flows, } \\
\text { including activity behaviour, } \\
\text { changes in land use, and effects } \\
\text { on environment }\end{array}$ & $\begin{array}{l}\text { Human sphere (activity patterns } \\
\text { and travel demand, traffic flows, } \\
\text { goods transport, accessibility of } \\
\text { locations, location decisions of } \\
\text { households, firms, developers) } \\
\text { Land use (moving households, lo- } \\
\text { cation of firms, investment of de- } \\
\text { velopers, new industrial area) } \\
\text { Environment (clean air, traffic } \\
\text { noise) }\end{array}$ & $\begin{array}{l}\text { Strauch } \\
\text { et al. }(2003) \text {; } \\
\text { Moeckel et al. } \\
\text { (2006) }\end{array}$ \\
\hline ABM_2 & $\begin{array}{l}\text { Evolution of an entire urban re- } \\
\text { gion with emphasis on transporta- } \\
\text { tion }\end{array}$ & $\begin{array}{l}\text { Human sphere (location choice, ac- } \\
\text { tivity schedule, activity patterns, } \\
\text { automobile ownership, travel de- } \\
\text { mand) } \\
\text { Land use (land development, } \\
\text { transportation network) }\end{array}$ & $\begin{array}{l}\text { Salvini and } \\
\text { Miller (2005); } \\
\text { Miller et al. } \\
\text { (2004) }\end{array}$ \\
\hline
\end{tabular}


Table 1 - Continued

\begin{tabular}{|c|c|c|c|}
\hline Model & Main purpose & Components & Reference \\
\hline ABM_3 & $\begin{array}{l}\text { Predicting urbanisation with be- } \\
\text { havioural agents }\end{array}$ & $\begin{array}{l}\text { Human sphere (demographic } \\
\text { change, decisions of individuals) }\end{array}$ & $\begin{array}{l}\text { Ettema et al. } \\
(2007)\end{array}$ \\
\hline ABM_4 & $\begin{array}{l}\text { Development of built-up area } \\
\text { in peri-urban region, driven by } \\
\text { households and entrepreneurs; ur- } \\
\text { ban growth with different growth } \\
\text { rates }\end{array}$ & $\begin{array}{l}\text { Human sphere (households, jobs, } \\
\text { numbers of people, households } \\
\text { and workplaces at the start of the } \\
\text { year, average travel time to dis- } \\
\text { trict centres and capital city) } \\
\text { Land use (urban land, open space, } \\
\text { forest area) }\end{array}$ & $\begin{array}{l}\text { Loibl et al. } \\
(2007)\end{array}$ \\
\hline ABM_5 & $\begin{array}{l}\text { Link between transport and land } \\
\text { use; impact of different planning } \\
\text { strategies }\end{array}$ & $\begin{array}{l}\text { Human sphere (population, house- } \\
\text { holds, employment, travel demand, } \\
\text { accessibility, mobility, real estate, } \\
\text { land price) } \\
\text { Land use }\end{array}$ & $\begin{array}{l}\text { Waddell } \\
(2006) ; \text { Wad- } \\
\text { dell et al. } \\
(2003)\end{array}$ \\
\hline
\end{tabular}




\section{Representation of urban landscapes}

One of the major aspects which urban land use models have to represent are causalities and feedbacks related to human-nature interactions. The main components representing an urban system, according to the models under review, are summarised in Tables 1 and 2. Spatial Economic models are labelled SE, Cellular Automata CA, System Dynamics Models SD, and Agent-Based models ABM.

Table 2: Main components of urban systems - do the models under review include them?

\begin{tabular}{|c|c|c|c|}
\hline & Human sphere & Land use & Environment \\
\hline \multicolumn{4}{|c|}{ (Spatial) Economic models } \\
\hline SE_1 & $\mathrm{x}$ & $\mathrm{x}$ & \\
\hline SE_2 & $\mathrm{x}$ & $\mathrm{x}$ & \\
\hline \multicolumn{4}{|c|}{ System dynamics } \\
\hline SD_1 & $\mathrm{x}$ & $\mathrm{x}$ & $\mathrm{x}$ \\
\hline SD_2 & $\mathrm{x}$ & $\mathrm{x}$ & \\
\hline SD_3 & & $\mathrm{x}$ & $\mathrm{x}$ \\
\hline SD_4 & $\mathrm{x}$ & $\mathrm{x}$ & \\
\hline SD_5 & $\mathrm{x}$ & & $\mathrm{x}$ \\
\hline SD_6 & $\mathrm{x}$ & $\mathrm{x}$ & \\
\hline SD_7 & & $\mathrm{x}$ & \\
\hline \multicolumn{4}{|c|}{ Cellular automata } \\
\hline CA_1 & $\mathrm{x}$ & & \\
\hline CA_2 & $\mathrm{x}$ & $\mathrm{x}$ & \\
\hline CA_3 & $\mathrm{x}$ & $\mathrm{x}$ & $\mathrm{x}$ \\
\hline CA_4 & $\mathrm{x}$ & & $\mathrm{x}$ \\
\hline CA_5 & & & $\mathrm{x}$ \\
\hline \multicolumn{4}{|c|}{ Agent-based models } \\
\hline ABM_1 & $\mathrm{x}$ & $\mathrm{x}$ & \\
\hline ABM_2 & $\mathrm{x}$ & $\mathrm{x}$ & $\mathrm{x}$ \\
\hline ABM_3 & $\mathrm{x}$ & $\mathrm{x}$ & \\
\hline ABM_4 & $\mathrm{x}$ & $\mathrm{x}$ & \\
\hline ABM_5 & $\mathrm{x}$ & $\mathrm{x}$ & \\
\hline
\end{tabular}

Structural relationships between model components and variables are found to be very different in the models (Figures 2 and 3). This is due to the fact that levels of rules for land use change vary largely, depending on the modelling technique used, i.e., (spatial) economics, system dynamics, cellular automata or agent behaviour (Table 2).

The first model group, (spatial) economic or econometric models, sets up a formalised relationship between population and market; in our case these compounds are the housing market and residential land use. Spatial economics models can be dynamic (when model parameters are treated endogeneously) or quasi dynamic (if model parameters are fixed or an exogeneous input during the model runtime). Generally, such models define a demand based on a population/household/cohort, etc., number, but only a limited feedback is generated from the net supply to the original driver (in our case: population). Cellular automata derive probabilities of land use change for a certain cell out of historical land use data (Engelen et al., 2007; Barredo et al., 2003) or by using try-and-error "calibrations" (Hansen, 2007). Therefore, they do not explicitly deal with causal relationships between urban drivers and land use states. Driving forces of the human sphere, such

Living Reviews in Landscape Research

http://www. livingreviews.org/lrlr-2009-2 
as population dynamics, residential mobility or price elasticise of the real estate market, can be included as scenario assumptions in some of the models in order to define the magnitude of urban sprawl (e.g., CA_2, CA_4). Nevertheless, the decision about which cells change their land use in which way is based upon historical land use change patterns. In contrast, landscape properties like topography, hydrography or morphology are reflected in most of the cellular models (CA_1; CA_3-CA_5; Table 2). Using a different approach, agent-based models include individual and institutional actors to explicitly simulate processes of land use conversion. The main actors in these models are individuals or households, which choose their residential location according to their preferences, local industries and businesses which choose their location and employ local people, and institutions, which steer land use development by planning, permitting or restricting land use change, et cetera. Therefore, these models explicitly name the decision-making processes relevant for urban land use changes (ABM_1-ABM_5). System dynamics models lie between these two "extremes": They include the processes, but in an aggregate way without incorporating single actors and their individual goals (Table 2).

In the following, the processes captured in the simulation models are analysed with respect to the feedbacks mentioned in Section 2.

\subsection{Spidergrams}

For comparison purposes, we set up an assessment matrix, in which the degree of fulfilment of the four relationships (cf. again Figure 1) is assigned to each of the models under review. We used a metric scale from 0 to 2: If the criterion is fulfilled, then the "mark" 2 is given; if only parts of the criterion are fulfilled - e.g., the processes implemented by rudimentary or very simple - the "mark" 1 is given; and if the criterion is not at all fulfilled or not included in the model, the "mark" 0 is given. The results of the model assessment are given in forms of simple multicriteria spidergrams which compare the three types of models (SE, SD, CA and ABM; Figure 2) for all criteria and, in a second range of graphs, all models for each single criterion (Figure 3).

\subsection{Relationships between human sphere and land use}

Most of the models under review represent the impact of human sphere on land use. Table 1 provides an overview of the model components. Except for three model approaches, each model covers population dynamics and housing or built-up land, which belong to the major variables either for human sphere or land use. The spidergram in Figure 2 clearly shows that causal relationships between human drivers are better captured than the reverse feedback from urban land development to the human drivers. Agent-based approaches mainly cover both loops, since land use variables belong to the neighbourhood of the agents and thus directly influence decision making. In comparison, spatial economics and system dynamics models comprehensively cover loops of type 1 "human sphere to land use," but mostly neglect effects of changing urban land use on population dynamics or economic development. Cellular automata do include some feedbacks from the effects of land use changes on the human sphere.

\subsection{Impact of land use on environment}

Only very few simulation models close the loop between driving forces and environmental impacts. Cellular automata perform better in capturing the effects of relatively simple rule-based or neighbourhood-statistic driven land use changes on the environment. Since they are often spatially explicit, landscapes can be more easily represented (cf. again Figure 2). For example, in CA_3, the impact of urbanisation on biodiversity is assessed, but no feedback to driving forces is taken into account. In SD_7, the impact of transport on the environment is integrated, but it is not 

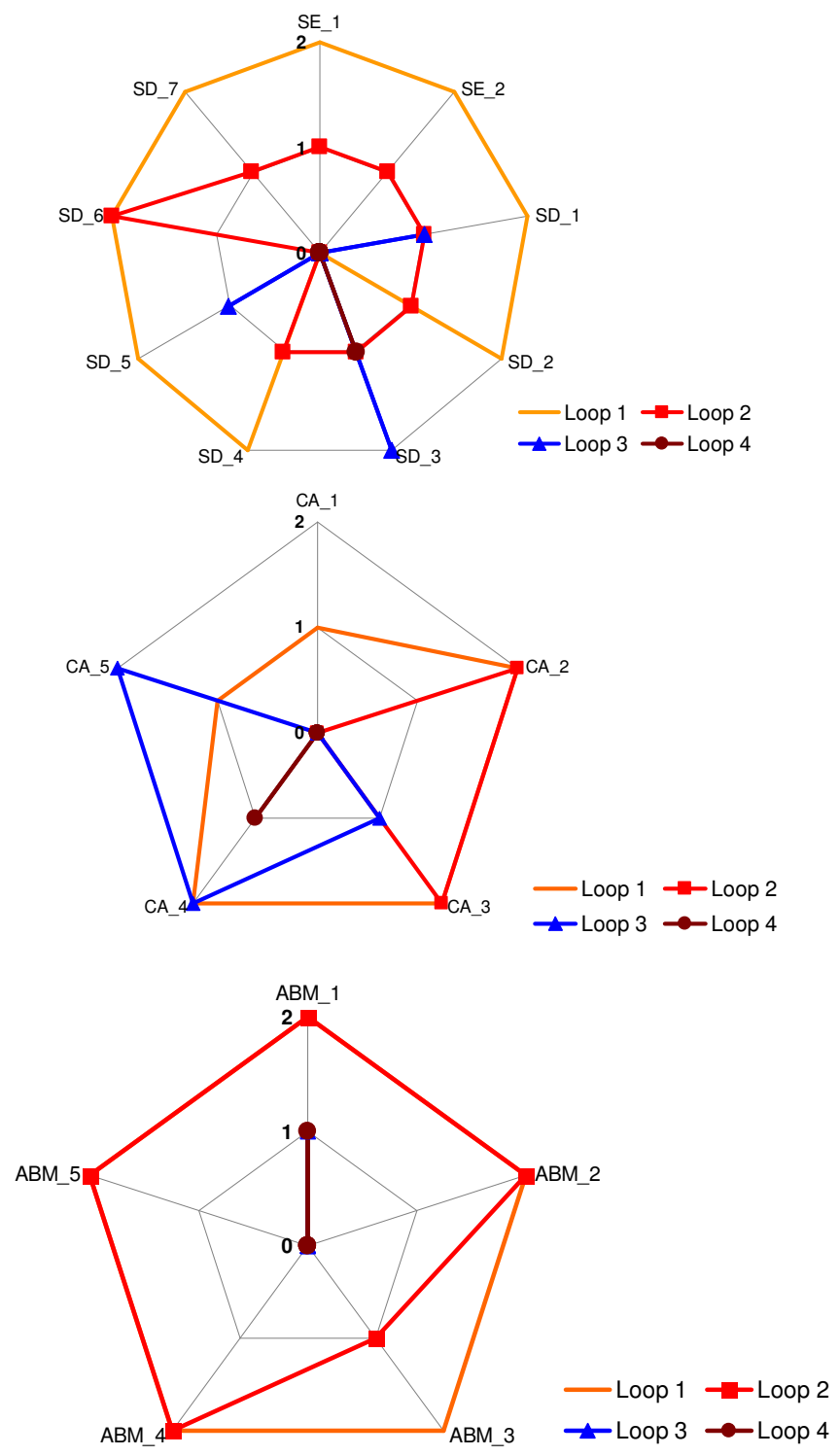

Figure 2: Spidergrams showing how far the reviewed models (according to their model type) incorporate the four relationships set up for model evaluation. 
Loop 1: Human sphere to land use

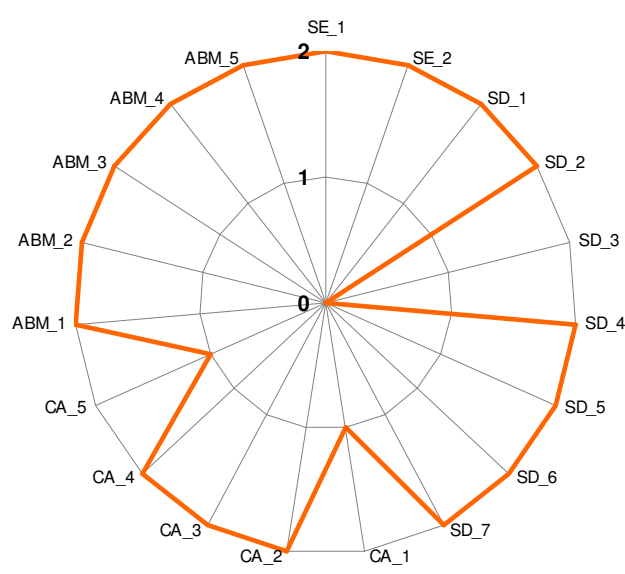

Loop 3: Land use to environment

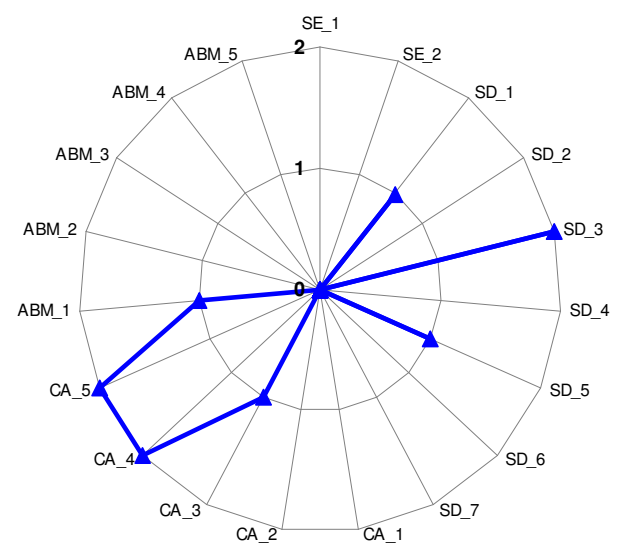

Loop 2: Land use to human sphere

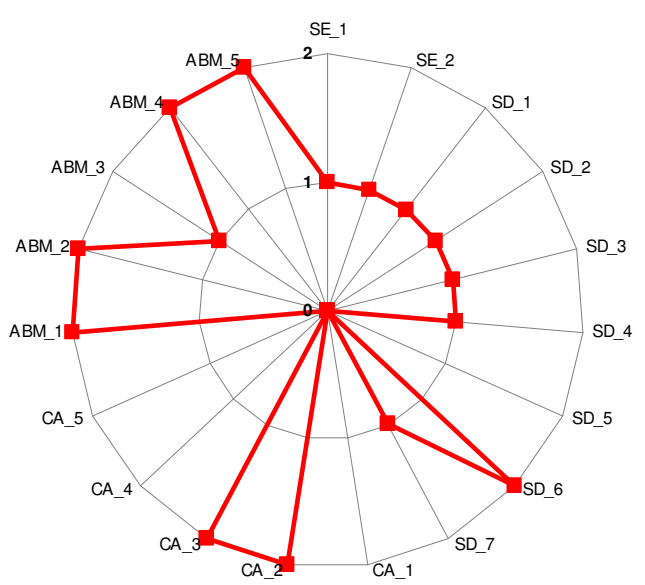

Loop 4: Environment to human sphere

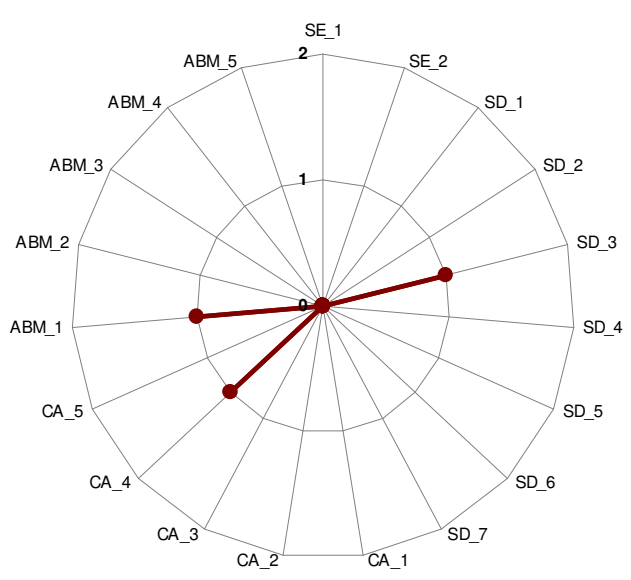

Figure 3: Spidergrams showing to which extent all reviewed models include the four loops. 
clear from the available literature if there is a feedback to driving forces (travel and transportation flows). The two economics models under review (SE_1 and SE_2) lack spatial explicitness to be able to capture a more comprehensive land use relation or feedback.

\subsection{Feedback from environment to human sphere}

Feedbacks from environmental impacts back to the driving forces that cause urban land use change are mostly realised through changing attractiveness of grid cells or regions for household residential location choices. Those were found in ABM_4 (open space, forest area), ABM_1 (traffic noise, air quality), CA_4 (quality and availability of space for activities), and SD_5 (traffic volume produces air pollution and thus affects human quality of life). In SD_3, the decrease of wetland area (and its negative impact on biodiversity) directly influences decisions to buy land for nature protection instead of further urbanisation. These relationships are the only ones that close the loop from households/individuals as drivers of land use change to environmental impacts and back to the original decision algorithm.

\subsection{Feedbacks between local and regional scale}

Feedbacks between the local and regional scale can be realised in a variety of ways: first, migration of population within single districts can have an influence on the attractiveness of the districts and therefore influence the housing market in the region, which in turn affects migration. Second, planning and governance on the regional scale can influence local land use changes, which in turn can impact regional planning. In several of the models, the housing market (or price development) is captured implicitly or explicitly. For example, in the spatial economics models SE_1 and SE_2, as well as in the system dynamics models SD_2 and SD_4, the housing market and housing development are explicitly included: In the two former cases in the form of real case study examples (Amsterdam and the U.S.), while in SD_2 an artificial market is created between expansionists and conservationists who want to buy open land - either in order to turn it into urban area or to conserve it. In cellular automata, prices for housing are not explicitly included. Probabilities for land use change can be regarded as bids for (re-)development (CA_2). In some of the agent-based models, real estate markets are already included or are planned to be included (e.g., ABM_1, ABM_3, ABM_5). In these models, developers are agents who can influence the market and therefore also the prices. Governmental planning processes are never explicitly represented in a way that governmental agencies are actors within the model. In some models, planning decisions are integrated as a part of the scenario configuration, e.g., by restricting or promoting possible evolution paths for certain grid cells (e.g., MOLAND). In others, construction and demolition are exogeneous variables (Nijkamp et al., 1993). But in these cases, planning decisions or housing market trends are not changed during the simulation, so that no feedbacks are established.

Living Reviews in Landscape Research

http://www. livingreviews . org/lrlr-2009-2 


\section{Conclusions}

The main purpose of this review was to analyse causalities and feedback loops in current urban land use change models. Therefore, we analysed 19 simulation models stemming from four different simulation methodologies: spatial economics, system dynamics, cellular automata, and agent-based modelling. The main conclusion of this review is that there is a range of comprehensive urban land use change models but no unique approach to represent urban landscapes and human-nature interactions. Each author or working group has its own view and focuses on other parts of the urban system and the relationships within that system. Thus, the landscape aspect is of minor importance. Most of the approaches bear the potential to model local and regional urban processes, as they provide a multitude of components and variables. However, currently only a few models integrate direct or indirect feedback loops from environmental and landscape-related impacts of urban land use change on environment to the respective driving forces in the human sphere of the systems. We see the reason for this in the gap between social science methods and findings, and computational models (cf. Geist and Lambin, 2004, 2002). The former comprehensively cover behavioural heuristics on decision making but are often qualitative in nature. The latter need quantitative (sometimes spatially explicit) input data or at least simple rules to be coded and thus incorporated into the models. To bring both approaches together and to better incorporate qualitative, social science data into quantitative models is still one of the major challenges of urban land use and landscape modelling. This is a challenge, not only for modellers, since empirical data for formulating a resilient feedback loop, resulting from environmental impacts on human quality of life and decision making, is rarely available (Haase and Haase, 2008). As urban systems are open systems which do not depend on local or regional natural resources and ecosystem services, neither individual nor policy decisions strongly depend on the availability and state of nature of the surroundings (cf. Haase and Nuissl, 2007). This makes it more difficult to elicit and formalise resilient feedbacks from the environment or landscape back to the driver. Another challenge is to express urban land use relationships, and in particular the aforementioned decision making in a spatially explicit way, as most of the CA models under review do. Finally, relationships between the local and regional scale are realised only with respect to housing markets, as single choices on the local scale are able to influence regional markets and vice versa. None of the models deals with all possible linkages between "the built-up urban" and "the rural" landscape within an urban region, although $\mathrm{CA}$ models such as MOLAND cover both types of land use, at least in terms of land use types. Current "hotspots" of the worldwide agri-environmental discussion, such as biofuels and organic farming, should also be partially incorporated into urban models. Here, we see another way to introduce more landscape aspects into urban land use modelling. 


\section{Acknowledgements}

This work is based on a deliverables for the PLUREL Integrated Project (Peri-urban Land Use Relationships) funded by the European Commission, Directorate-General for Research, under the 6th Framework Programme (project reference: 36921). This paper reflects the authors' views and not those of the European Community. Neither the European Community nor any member of the PLUREL Consortium is liable for any use of the information in this paper. The authors thank Klaus Steinocher, Nick Green, and anonymous reviewers for comments on earlier versions of this manuscript.

\section{Annex}

Within the following tables (describing the models in alphabetical order), empty cells indicate that no information was found in the literature on this issue. "_" in a cell means that this issue is not applicable to the model in question.

Field "Duration of model run:"

- C: Calibration to fit model parameters

- S: Scenarios for projections of future trends

- V: Validation using independent data 
Table 3: Household life cycle model for residential relocation behaviour [SE_1]

\begin{tabular}{|c|c|c|c|c|}
\hline Name of model & \multicolumn{4}{|c|}{ Household life cycle model for residential relocation behaviour } \\
\hline Sources & \multicolumn{4}{|c|}{ Nijkamp et al. (1993) } \\
\hline \multicolumn{5}{|l|}{ Technical data } \\
\hline \multirow[t]{2}{*}{ Application area } & $\begin{array}{l}\text { Covered } \\
\text { area, physical } \\
\text { boundaries }\end{array}$ & $\begin{array}{l}\text { Case study: } \\
\text { Greater Amster- } \\
\text { dam Area }\end{array}$ & Extent of area & $\begin{array}{l}350 \text { square miles } \\
\text { / About } 800,000 \\
\text { people }\end{array}$ \\
\hline & Spatial units & 20 zones & $\begin{array}{l}\text { Size or grain of } \\
\text { grids/zones }\end{array}$ & - \\
\hline Time horizon & Time step & 1 year & $\begin{array}{l}\text { Duration of } \\
\text { model run }\end{array}$ & $1971-1984$ \\
\hline $\begin{array}{l}\text { Modelling ap- } \\
\text { proach }\end{array}$ & $\begin{array}{l}\text { Simulation } \\
\text { technique }\end{array}$ & Spatial economics & $\begin{array}{l}\text { Qualitative or } \\
\text { quantitative }\end{array}$ & Quantitative \\
\hline \multicolumn{5}{|l|}{ Contents } \\
\hline Main purpose & \multicolumn{4}{|c|}{$\begin{array}{l}\text { Modelling household life cycles and their impact on residential relocation be- } \\
\text { haviour and the urban housing market for a European capital city. }\end{array}$} \\
\hline $\begin{array}{l}\text { Main variables } \\
\text { with relationships }\end{array}$ & \multicolumn{4}{|c|}{$\begin{array}{l}\text { (1) households, (2) migration, (3) occupancy, (4) housing demand, (5) dwelling } \\
\text { supply in zones and dwelling types, (6) allocation of households. }\end{array}$} \\
\hline \multirow{3}{*}{$\begin{array}{l}\text { Human decision } \\
\text { making }\end{array}$} & Domain & Not explicitly & $\begin{array}{l}\text { Temporal } \\
\text { range }\end{array}$ & - \\
\hline & $\begin{array}{l}\text { Typology } \\
\text { (classes) of } \\
\text { agents? }\end{array}$ & $\begin{array}{l}\text { Allocation of } \\
\text { household }\end{array}$ & $\begin{array}{l}\rightarrow \text { if yes: what } \\
\text { types? }\end{array}$ & $\begin{array}{l}\text { Households: single, } \\
\text { 2-person house- } \\
\text { hold, 3-person } \\
\text { household, } 4+ \\
\text { person household, } \\
\text { non-household }\end{array}$ \\
\hline & $\begin{array}{l}\text { Decision algo- } \\
\text { rithm }\end{array}$ & $\begin{array}{l}\text { Rational choice, } \\
\text { maximum utility }\end{array}$ & $\begin{array}{l}\text { Input into de- } \\
\text { cision }\end{array}$ & $\begin{array}{l}\text { Population and } \\
\text { household data }\end{array}$ \\
\hline Goals & $\begin{array}{l}\text { Authors' opin- } \\
\text { ion }\end{array}$ & \multicolumn{3}{|c|}{ Successful runs, validation and scenarios. } \\
\hline $\begin{array}{l}\text { Model development } \\
\text { process }\end{array}$ & Concept & Given & $\begin{array}{l}\text { Quantification } \\
\text { of relationships }\end{array}$ & Empirical data \\
\hline
\end{tabular}


Table 4: Simulation of demographic changes and the housing market [SE_2]

\begin{tabular}{|c|c|c|c|c|}
\hline Name of model & \multicolumn{4}{|c|}{ Simulation of demographic changes and the housing market } \\
\hline Sources & \multicolumn{4}{|c|}{ Mankiw and Weil (1989) } \\
\hline \multicolumn{5}{|l|}{ Technical data } \\
\hline \multirow[t]{2}{*}{ Application area } & $\begin{array}{l}\text { Covered } \\
\text { area, physical } \\
\text { boundaries }\end{array}$ & U.S. cities (census) & Extent of area & $\begin{array}{l}-/ 203,190 \text { people } \\
\text { / } 74,565 \text { house- } \\
\text { holds }\end{array}$ \\
\hline & Spatial units & U.S. cities (census) & $\begin{array}{l}\text { Size or grain of } \\
\text { grids/zones }\end{array}$ & - \\
\hline Time horizon & Time step & 1 year & $\begin{array}{l}\text { Duration of } \\
\text { model run }\end{array}$ & $1970-2007$ or 2020 \\
\hline $\begin{array}{l}\text { Modelling ap- } \\
\text { proach }\end{array}$ & $\begin{array}{l}\text { Simulation } \\
\text { technique }\end{array}$ & Spatial economics & $\begin{array}{l}\text { Qualitative or } \\
\text { quantitative }\end{array}$ & Quantitative \\
\hline \multicolumn{5}{|l|}{ Contents } \\
\hline Main purpose & \multicolumn{4}{|c|}{$\begin{array}{l}\text { Simulation of demographic changes (baby boom and baby bust) and its influ- } \\
\text { ences on the housing market in the U.S. }\end{array}$} \\
\hline $\begin{array}{l}\text { Main variables } \\
\text { with relationships }\end{array}$ & \multicolumn{4}{|c|}{$\begin{array}{l}\text { (1) population, (2) households, (3) housing market (demand, prices), (4) econ- } \\
\text { omy (GNP) }\end{array}$} \\
\hline \multirow{3}{*}{$\begin{array}{l}\text { Human decision } \\
\text { making }\end{array}$} & Domain & Not explicitly & $\begin{array}{l}\text { Temporal } \\
\text { range }\end{array}$ & - \\
\hline & $\begin{array}{l}\text { Typology } \\
\text { (classes) of } \\
\text { agents? }\end{array}$ & $\begin{array}{l}\text { Allocation of } \\
\text { household }\end{array}$ & $\begin{array}{l}\rightarrow \text { if yes: what } \\
\text { types? }\end{array}$ & Dummy household \\
\hline & $\begin{array}{l}\text { Decision algo- } \\
\text { rithm }\end{array}$ & $\begin{array}{l}\text { Rational choice, } \\
\text { maximum utility }\end{array}$ & $\begin{array}{l}\text { Input into de- } \\
\text { cision }\end{array}$ & Census data \\
\hline Goals & $\begin{array}{l}\text { Authors' opin- } \\
\text { ion }\end{array}$ & \multicolumn{3}{|c|}{ Successful runs, validation and scenarios. } \\
\hline $\begin{array}{l}\text { Model development } \\
\text { process }\end{array}$ & Concept & Given & $\begin{array}{l}\text { Quantification } \\
\text { of relationships }\end{array}$ & Empirical data \\
\hline
\end{tabular}


Table 5: A System Dynamics Approach to Land Use / Transportation System Performance Modeling [SD_2]

\begin{tabular}{|c|c|c|c|c|}
\hline Name of model & \multicolumn{4}{|c|}{$\begin{array}{l}\text { A System Dynamics Approach to Land Use / Transportation System Perfor- } \\
\text { mance Modeling }\end{array}$} \\
\hline Sources & \multicolumn{4}{|c|}{ Haghani et al. (2003a,b) } \\
\hline \multicolumn{5}{|l|}{ Technical data } \\
\hline \multirow[t]{2}{*}{ Application area } & $\begin{array}{l}\text { Covered } \\
\text { area, physical } \\
\text { boundaries }\end{array}$ & $\begin{array}{l}\text { Varies with appli- } \\
\text { cation area; Case } \\
\text { study: Montgomery } \\
\text { County }\end{array}$ & Extent of area & $\begin{array}{l}-/ \text { About } 800,000 \\
\text { people }\end{array}$ \\
\hline & Spatial units & U.S. cities (census) & $\begin{array}{l}\text { Size or grain of } \\
\text { grids/zones }\end{array}$ & - \\
\hline Time horizon & Time step & 1 year & $\begin{array}{l}\text { Duration of } \\
\text { model run }\end{array}$ & $\begin{array}{l}\text { C: } 1970-1980 \\
\text { V: } 1980-1990\end{array}$ \\
\hline $\begin{array}{l}\text { Modelling ap- } \\
\text { proach }\end{array}$ & $\begin{array}{l}\text { Simulation } \\
\text { technique }\end{array}$ & Spatial economics & $\begin{array}{l}\text { Qualitative or } \\
\text { quantitative }\end{array}$ & Quantitative \\
\hline \multicolumn{5}{|l|}{ Contents } \\
\hline Main purpose & \multicolumn{4}{|c|}{$\begin{array}{l}\text { Integrated land-use and transportation model for estimating scenarios regard- } \\
\text { ing transport policies }\end{array}$} \\
\hline $\begin{array}{l}\text { Main variables } \\
\text { with relationships }\end{array}$ & \multicolumn{4}{|c|}{$\begin{array}{l}\text { Seven sub-models: (1) population, (2) migration, (3) household, (4) job } \\
\text { growth, employment and commercial land development, (5) housing devel- } \\
\text { opment, (6) travel demand and ( } 7) \text { congestion. }\end{array}$} \\
\hline \multirow{3}{*}{$\begin{array}{l}\text { Human decision } \\
\text { making }\end{array}$} & Domain & Not explicitly & $\begin{array}{l}\text { Temporal } \\
\text { range }\end{array}$ & - \\
\hline & $\begin{array}{l}\text { Typology } \\
\text { (classes) of } \\
\text { agents? }\end{array}$ & $\begin{array}{l}\text { Cohorts within } \\
\text { population sub- } \\
\text { model }\end{array}$ & $\begin{array}{l}\rightarrow \text { if yes: what } \\
\text { types? }\end{array}$ & $\begin{array}{l}\text { Persons: age } 0-17 \text {, } \\
18-44,45-64,65 \\
\text { male and female / } \\
\text { Households: single, } \\
\text { married with chil- } \\
\text { dren, married with- } \\
\text { out children, male } \\
\text { or female with chil- } \\
\text { dren, other }\end{array}$ \\
\hline & $\begin{array}{l}\text { Decision algo- } \\
\text { rithm }\end{array}$ & - & $\begin{array}{l}\text { Input into de- } \\
\text { cision }\end{array}$ & - \\
\hline Goals & $\begin{array}{l}\text { Authors' opin- } \\
\text { ion }\end{array}$ & \multicolumn{3}{|c|}{$\begin{array}{l}\text { First step is achieved, successful validation and scenar- } \\
\text { ios. }\end{array}$} \\
\hline $\begin{array}{l}\text { Model development } \\
\text { process }\end{array}$ & Concept & Not stated & $\begin{array}{l}\text { Quantification } \\
\text { of relationships }\end{array}$ & Empirical data \\
\hline
\end{tabular}


Table 6: CLUE-s (Conversion of Land Use and its Effects) [CA_1]

\begin{tabular}{|c|c|c|c|c|}
\hline Name of model & \multicolumn{4}{|c|}{ CLUE-s (Conversion of Land Use and its Effects) } \\
\hline Sources & \multicolumn{4}{|c|}{ Verburg and Overmars (2007) } \\
\hline \multicolumn{5}{|l|}{ Technical data } \\
\hline \multirow[t]{2}{*}{ Application area } & $\begin{array}{l}\text { Covered } \\
\text { area, physical } \\
\text { boundaries }\end{array}$ & $\begin{array}{l}\text { User-specified / } \\
\text { Several examples } \\
\text { published }\end{array}$ & Extent of area & User-specified \\
\hline & Spatial units & $\begin{array}{l}\text { CLUE: soft- } \\
\text { classified data } \\
\text { (large pixels with } \\
\text { fraction of land- } \\
\text { uses) }\end{array}$ & $\begin{array}{l}\text { Size or grain of } \\
\text { grids/zones }\end{array}$ & $\begin{array}{l}\text { User-specified / } \\
\text { CLUE: } 7 \text { to } 32 \mathrm{~km} \\
\text { / CLUE-s: } \\
20 \text { to } 1,000 \mathrm{~m}\end{array}$ \\
\hline Time horizon & Time step & $\begin{array}{l}\text { Iterative process } \\
\text { stops when de- } \\
\text { mand for land-use } \\
\text { meets allocated } \\
\text { area }\end{array}$ & $\begin{array}{l}\text { Duration of } \\
\text { model run }\end{array}$ & - \\
\hline $\begin{array}{l}\text { Modelling ap- } \\
\text { proach }\end{array}$ & $\begin{array}{l}\text { Simulation } \\
\text { technique }\end{array}$ & Cellular automata & $\begin{array}{l}\text { Qualitative or } \\
\text { quantitative }\end{array}$ & Quantitative \\
\hline \multicolumn{5}{|l|}{ Contents } \\
\hline Main purpose & \multicolumn{4}{|c|}{$\begin{array}{l}\text { Tool for understanding land-use patterns, possible future scenarios for given } \\
\text { demand }\end{array}$} \\
\hline $\begin{array}{l}\text { Main variables } \\
\text { with relationships }\end{array}$ & \multicolumn{4}{|c|}{$\begin{array}{l}\text { Input: Pre-defined change in demand for land by different sectors for whole } \\
\text { simulation area } \rightarrow \text { CLUE-s assigns new land-uses per grid } \\
\text { Each cell: most preferred land use based on suitability of location and com- } \\
\text { petitive advantage of different land use types (demand), check: is land use } \\
\text { change allowed? If no: next most preferred land use is chosen }\end{array}$} \\
\hline \multirow{3}{*}{$\begin{array}{l}\text { Human decision } \\
\text { making }\end{array}$} & Domain & $\begin{array}{l}\text { Not explicit deci- } \\
\text { sion making }\end{array}$ & $\begin{array}{l}\text { Temporal } \\
\text { range }\end{array}$ & - \\
\hline & $\begin{array}{l}\text { Typology } \\
\text { (classes) of } \\
\text { agents? }\end{array}$ & - & $\begin{array}{l}\rightarrow \text { if yes: what } \\
\text { types? }\end{array}$ & - \\
\hline & $\begin{array}{l}\text { Decision algo- } \\
\text { rithm }\end{array}$ & - & $\begin{array}{l}\text { Input into de- } \\
\text { cision }\end{array}$ & - \\
\hline Goals & $\begin{array}{l}\text { Authors' opin- } \\
\text { ion }\end{array}$ & \multicolumn{3}{|l|}{ Case-study specific } \\
\hline $\begin{array}{l}\text { Model development } \\
\text { process }\end{array}$ & Concept & Not mentioned & $\begin{array}{l}\text { Quantification } \\
\text { of relationships }\end{array}$ & $\begin{array}{l}\text { User-specified: em- } \\
\text { pirical analysis, } \\
\text { expert knowledge, } \\
\text { spatial interactions, } \\
\text { conversion elastici- } \\
\text { ties }\end{array}$ \\
\hline
\end{tabular}


Table 7: CUF-2 (California Urban Futures) [CA_2]

\begin{tabular}{|c|c|c|c|c|}
\hline Name of model & \multicolumn{4}{|c|}{ CUF 2 (California Urban Futures) } \\
\hline Sources & \multicolumn{4}{|c|}{ Landis and Zhang $(1998 \mathrm{a}, \mathrm{b})$} \\
\hline \multicolumn{5}{|l|}{ Technical data } \\
\hline \multirow[t]{2}{*}{ Application area } & $\begin{array}{l}\text { Covered } \\
\text { area, physical } \\
\text { boundaries }\end{array}$ & $\begin{array}{l}\text { San Francisco Bay } \\
\text { Area (California) }\end{array}$ & Extent of area & 1.8 million ha \\
\hline & Spatial units & Grid cells & $\begin{array}{l}\text { Size or grain of } \\
\text { grids/zones }\end{array}$ & $100 \times 100 \mathrm{~m}$ \\
\hline Time horizon & Time step & $\begin{array}{l}\text { Econometric: } \\
10 \text { years / Prob- } \\
\text { abilities for land } \\
\text { use change: once } \\
\text { per simulation }\end{array}$ & $\begin{array}{l}\text { Duration of } \\
\text { model run }\end{array}$ & $\begin{array}{l}\text { C: } 1985-1995 / \\
\text { S: ? }\end{array}$ \\
\hline $\begin{array}{l}\text { Modelling ap- } \\
\text { proach }\end{array}$ & $\begin{array}{l}\text { Simulation } \\
\text { technique }\end{array}$ & Cellular automata & $\begin{array}{l}\text { Qualitative or } \\
\text { quantitative }\end{array}$ & Quantitative \\
\hline \multicolumn{5}{|l|}{ Contents } \\
\hline Main purpose & \multicolumn{4}{|c|}{ Simulating urban growth, scenarios for future development } \\
\hline $\begin{array}{l}\text { Main variables } \\
\text { with relationships }\end{array}$ & \multicolumn{4}{|c|}{$\begin{array}{l}\text { Top-down approach: future trends of population, household, jobs } \rightarrow \text { are } \\
\text { assigned to grid cells } \\
\text { Econometric models predict future population, households, employment } \\
\text { (10 year intervals) } \\
\text { LUC-model: estimates probabilities for land use change out of historical } \\
\text { data, and simulation engine assigns probabilities to cells } \\
\text { Probability of land use change (multinomial logit models) for a cell from } \\
\text { i to j = f (initial site use, site characteristics, site accessibility, community } \\
\text { characteristics, policy factors, relationships to neighbouring sites) } \rightarrow \text { proba- } \\
\text { bilities are interpreted as bids for (re-)development } \rightarrow \text { population and jobs } \\
\text { are assigned to cells by bids } \\
7 \text { urban land-use categories: undeveloped, single-family residential, multi- } \\
\text { family residential, commercial, industrial, transportation, public }\end{array}$} \\
\hline \multirow{3}{*}{$\begin{array}{l}\text { Human decision } \\
\text { making }\end{array}$} & Domain & $\begin{array}{l}\text { Not explicit deci- } \\
\text { sion making }\end{array}$ & $\begin{array}{l}\text { Temporal } \\
\text { range }\end{array}$ & - \\
\hline & $\begin{array}{l}\text { Typology } \\
\text { (classes) of } \\
\text { agents? }\end{array}$ & - & $\begin{array}{l}\rightarrow \text { if yes: what } \\
\text { types? }\end{array}$ & - \\
\hline & $\begin{array}{l}\text { Decision algo- } \\
\text { rithm }\end{array}$ & - & $\begin{array}{l}\text { Input into de- } \\
\text { cision }\end{array}$ & - \\
\hline Goals & $\begin{array}{l}\text { Authors' opin- } \\
\text { ion }\end{array}$ & Achieved & & \\
\hline $\begin{array}{l}\text { Model development } \\
\text { process }\end{array}$ & Concept & Not mentioned & $\begin{array}{l}\text { Quantification } \\
\text { of relationships }\end{array}$ & $\begin{array}{l}\text { Calibration using } \\
\text { maps of land use } \\
\text { change }\end{array}$ \\
\hline
\end{tabular}


Table 8: CURBA (California Urban and Biodiversity Analysis)(CA_3]

\begin{tabular}{|c|c|c|c|c|}
\hline Name of model & \multicolumn{4}{|c|}{ CURBA (California Urban and Biodiversity Analysis) } \\
\hline Sources & \multicolumn{4}{|c|}{ Landis et al. (1998) } \\
\hline \multicolumn{5}{|l|}{ Technical data } \\
\hline \multirow[t]{2}{*}{ Application area } & $\begin{array}{l}\text { Covered } \\
\text { area, physical } \\
\text { boundaries }\end{array}$ & $\begin{array}{l}\text { San Francisco Bay } \\
\text { Area (California) }\end{array}$ & Extent of area & See CUF-2 \\
\hline & Spatial units & Grid cells & $\begin{array}{l}\text { Size or grain of } \\
\text { grids/zones }\end{array}$ & $100 \times 100 \mathrm{~m}$ \\
\hline Time horizon & Time step & & $\begin{array}{l}\text { Duration of } \\
\text { model run }\end{array}$ & \\
\hline $\begin{array}{l}\text { Modelling ap- } \\
\text { proach }\end{array}$ & $\begin{array}{l}\text { Simulation } \\
\text { technique }\end{array}$ & Cellular automata & $\begin{array}{l}\text { Qualitative or } \\
\text { quantitative }\end{array}$ & Quantitative \\
\hline \multicolumn{5}{|l|}{ Contents } \\
\hline Main purpose & \multirow{2}{*}{\multicolumn{4}{|c|}{$\begin{array}{l}\text { Development of policy scenarios of urban growth, impact on habitat } \\
\text { change/biodiversity } \\
\text { Two components: (1) urban growth model and (2) policy simulation and } \\
\text { evaluation model / Urban growth model is based upon CUF-2 } \\
\text { Policy simulation and evaluation: several growth scenarios } \rightarrow \text { impact on } \\
\text { habitat change and habitat fragmentation }\end{array}$}} \\
\hline $\begin{array}{l}\text { Main variables } \\
\text { with relationships }\end{array}$ & & & & \\
\hline \multirow{3}{*}{$\begin{array}{l}\text { Human decision } \\
\text { making }\end{array}$} & Domain & $\begin{array}{l}\text { No explicit decision } \\
\text { making }\end{array}$ & $\begin{array}{l}\text { Temporal } \\
\text { range }\end{array}$ & - \\
\hline & $\begin{array}{l}\text { Typology } \\
\text { (classes) of } \\
\text { agents? }\end{array}$ & - & $\begin{array}{l}\rightarrow \text { if yes: what } \\
\text { types? }\end{array}$ & - \\
\hline & $\begin{array}{l}\text { Decision algo- } \\
\text { rithm }\end{array}$ & - & $\begin{array}{l}\text { Input into de- } \\
\text { cision }\end{array}$ & - \\
\hline Goals & $\begin{array}{l}\text { Authors' opin- } \\
\text { ion }\end{array}$ & Achieved & & \\
\hline $\begin{array}{l}\text { Model development } \\
\text { process }\end{array}$ & Concept & See CUF-2 & $\begin{array}{l}\text { Quantification } \\
\text { of relationships }\end{array}$ & See CUF-2 \\
\hline
\end{tabular}


Table 9: ILUMASS (Integrated Land-Use Modelling and Transportation System Simulation) [ABM_1]

\begin{tabular}{|c|c|c|c|c|}
\hline Name of model & \multicolumn{4}{|c|}{$\begin{array}{l}\text { ILUMASS (Integrated Land-Use Modelling and Transportation System Sim- } \\
\text { ulation) }\end{array}$} \\
\hline Sources & \multicolumn{4}{|c|}{ Strauch et al. (2003); Moeckel et al. (2006) } \\
\hline \multicolumn{5}{|l|}{ Technical data } \\
\hline \multirow[t]{2}{*}{ Application area } & $\begin{array}{l}\text { Covered } \\
\text { area, physical } \\
\text { boundaries }\end{array}$ & $\begin{array}{l}\text { Dortmund and its } \\
25 \text { surrounding } \\
\text { municipalities }\end{array}$ & Extent of area & $\begin{array}{l}\text { About } 2,000 \mathrm{~km}^{2} / \\
2.6 \text { million people }\end{array}$ \\
\hline & Spatial units & $\begin{array}{l}\text { Statistical zones } \\
\text { (total: } 246 \text { ) and } \\
\text { grid cells }\end{array}$ & $\begin{array}{l}\text { Size or grain of } \\
\text { grids/zones }\end{array}$ & $\begin{array}{l}\text { Grid cells: } \\
100 \times 100 \mathrm{~m}\end{array}$ \\
\hline Time horizon & Time step & One year & $\begin{array}{l}\text { Duration of } \\
\text { model run }\end{array}$ & S: $2000-2030$ \\
\hline $\begin{array}{l}\text { Modelling ap- } \\
\text { proach }\end{array}$ & $\begin{array}{l}\text { Simulation } \\
\text { technique }\end{array}$ & $\begin{array}{l}\text { Coupled simulation } \\
\text { system including } \\
\text { agent-based simu- } \\
\text { lations }\end{array}$ & $\begin{array}{l}\text { Qualitative or } \\
\text { quantitative }\end{array}$ & Quantitative \\
\hline \multicolumn{5}{|l|}{ Contents } \\
\hline Main purpose & \multicolumn{4}{|c|}{$\begin{array}{l}\text { Dynamic simulation model with a focus on urban traffic flows, including ac- } \\
\text { tivity behaviour, changes in land use, and effects on environment }\end{array}$} \\
\hline $\begin{array}{l}\text { Main variables } \\
\text { with relationships }\end{array}$ & \multicolumn{4}{|c|}{$\begin{array}{l}\text { Five modules (+ integration module): } 1 \text {. changes in land use, } 2 \text {. activity } \\
\text { patterns and travel demand, } 3 \text {. traffic flows, } 4 \text {. goods transport, } 5 \text {. environ- } \\
\text { mental impacts of transportation and land use } \\
\text { Land use } \rightarrow \text { demand for spatial interaction (work, shopping trips, etc.) } \rightarrow \\
\text { traffic } \rightarrow \text { environmental impacts } \\
\text { Feedbacks: (a) transport } \rightarrow \text { accessibility of locations } \rightarrow \text { location decisions } \\
\text { of households, firms, developers. (b) environmental factors } \rightarrow \text { location deci- } \\
\text { sions (e.g., clean air, traffic noise) } \\
\text { Land use module: moving households, location of firms, investment of de- } \\
\text { velopers, new industrial area }\end{array}$} \\
\hline \multirow{3}{*}{$\begin{array}{l}\text { Human decision } \\
\text { making }\end{array}$} & Domain & $\begin{array}{l}\text { Various, e.g., trans- } \\
\text { port, household } \\
\text { location, daily ac- } \\
\text { tivity plans }\end{array}$ & $\begin{array}{l}\text { Temporal } \\
\text { range }\end{array}$ & $\begin{array}{l}\text { Depending upon } \\
\text { domain (daily } \\
\text { travel behaviour } \\
\text { vs. moving) }\end{array}$ \\
\hline & $\begin{array}{l}\text { Typology } \\
\text { (classes) of } \\
\text { agents? }\end{array}$ & Yes & $\begin{array}{l}\rightarrow \text { if yes: what } \\
\text { types? }\end{array}$ & Not mentioned \\
\hline & $\begin{array}{l}\text { Decision algo- } \\
\text { rithm }\end{array}$ & $\begin{array}{l}\text { Various (Markov, } \\
\text { Logit, Monte- } \\
\text { Carlo) }\end{array}$ & $\begin{array}{l}\text { Input into de- } \\
\text { cision }\end{array}$ & $\begin{array}{l}\text { Depending upon } \\
\text { domain, feedbacks } \\
\text { included }\end{array}$ \\
\hline Goals & $\begin{array}{l}\text { Authors' opin- } \\
\text { ion }\end{array}$ & \multicolumn{3}{|c|}{$\begin{array}{l}\text { Time of report: work in progress, later papers all focus } \\
\text { on single modules }\end{array}$} \\
\hline $\begin{array}{l}\text { Model development } \\
\text { process }\end{array}$ & Concept & Not mentioned & $\begin{array}{l}\text { Quantification } \\
\text { of relationships }\end{array}$ & Not mentioned \\
\hline
\end{tabular}


Table 10: ILUTE (Integrated Land Use, Transportation, Environment model) [ABM_2]

\begin{tabular}{|c|c|c|c|c|}
\hline Name of model & \multicolumn{4}{|c|}{ ILUTE (Integrated Land Use, Transportation, Environment model) } \\
\hline Sources & \multicolumn{4}{|c|}{ Salvini and Miller (2005); Miller et al. (2004) } \\
\hline \multicolumn{5}{|l|}{ Technical data } \\
\hline \multirow[t]{2}{*}{ Application area } & $\begin{array}{l}\text { Covered } \\
\text { area, physical } \\
\text { boundaries }\end{array}$ & $\begin{array}{l}\text { Tests for Toronto } \\
\text { area }\end{array}$ & Extent of area & 5 million people \\
\hline & Spatial units & $\begin{array}{l}\text { Two versions: grids } \\
\text { and buildings }\end{array}$ & $\begin{array}{l}\text { Size or grain of } \\
\text { grids/zones }\end{array}$ & $\begin{array}{l}2 \text { parallel ap- } \\
\text { proaches: Grid: } \\
30 \times 30 \mathrm{~m} / \text { Build- } \\
\text { ings as objects }\end{array}$ \\
\hline Time horizon & Time step & $\begin{array}{l}\text { Varying with sub- } \\
\text { models }\end{array}$ & $\begin{array}{l}\text { Duration of } \\
\text { model run }\end{array}$ & $\begin{array}{l}\text { V: } 1986-2001 / \mathrm{S}: \\
10-20 \text { years into } \\
\text { future }\end{array}$ \\
\hline $\begin{array}{l}\text { Modelling ap- } \\
\text { proach }\end{array}$ & $\begin{array}{l}\text { Simulation } \\
\text { technique }\end{array}$ & $\begin{array}{l}\text { Agent-based simu- } \\
\text { lation }\end{array}$ & $\begin{array}{l}\text { Qualitative or } \\
\text { quantitative }\end{array}$ & Quantitative \\
\hline \multicolumn{5}{|l|}{ Contents } \\
\hline Main purpose & \multicolumn{4}{|c|}{ Evolution of an entire urban region with emphasis on transport } \\
\hline $\begin{array}{l}\text { Main variables } \\
\text { with relationships }\end{array}$ & \multicolumn{4}{|c|}{$\begin{array}{l}\text { Land development } \rightarrow \text { location choice } \rightarrow \text { activity schedule } \rightarrow \text { activity patterns } \\
\rightarrow \text { back to land development and all other variables in chain transportation } \\
\text { network } \rightarrow \text { automobile ownership } \rightarrow \text { travel demand } \rightarrow \text { network flows } \rightarrow \text { back } \\
\text { to transportation network and all other variables in chain influences }\end{array}$} \\
\hline \multirow{3}{*}{$\begin{array}{l}\text { Human decision } \\
\text { making }\end{array}$} & Domain & $\begin{array}{l}\text { Activity/travelling } \\
\text { scheduling, route } \\
\text { choice, real es- } \\
\text { tate market, be- } \\
\text { haviour of econ- } \\
\text { omy, land devel- } \\
\text { opment, household } \\
\text { ownership }\end{array}$ & $\begin{array}{l}\text { Temporal } \\
\text { range }\end{array}$ & $\begin{array}{l}\text { Depends upon do- } \\
\text { main. E.g.: typical } \\
\text { travel day is com- } \\
\text { puted once per } \\
\text { simulation year per } \\
\text { agent type. }\end{array}$ \\
\hline & $\begin{array}{l}\text { Typology } \\
\text { (classes) of } \\
\text { agents? }\end{array}$ & Yes & $\begin{array}{l}\rightarrow \text { if yes: what } \\
\text { types? }\end{array}$ & $\begin{array}{l}\text { For households, } \\
\text { individuals, firms }\end{array}$ \\
\hline & $\begin{array}{l}\text { Decision algo- } \\
\text { rithm }\end{array}$ & $\begin{array}{l}\text { Rule-based: re- } \\
\text { ducing number } \\
\text { of choices / logit } \\
\text { model for selecting } \\
\text { the "best" option }\end{array}$ & $\begin{array}{l}\text { Input into de- } \\
\text { cision }\end{array}$ & Not mentioned \\
\hline Goals & $\begin{array}{l}\text { Authors' opin- } \\
\text { ion }\end{array}$ & \multicolumn{3}{|l|}{ Work in progress } \\
\hline $\begin{array}{l}\text { Model development } \\
\text { process }\end{array}$ & Concept & Not mentioned & $\begin{array}{l}\text { Quantification } \\
\text { of relationships }\end{array}$ & Empirical data \\
\hline
\end{tabular}


Table 11: Modelling biodiversity and land use [SD_3]

\begin{tabular}{|c|c|c|c|c|}
\hline Name of model & \multicolumn{4}{|c|}{ Modelling biodiversity and land use } \\
\hline Sources & \multicolumn{4}{|c|}{ Eppink et al. (2004) } \\
\hline \multicolumn{5}{|l|}{ Technical data } \\
\hline \multirow[t]{2}{*}{ Application area } & $\begin{array}{l}\text { Covered } \\
\text { area, physical } \\
\text { boundaries }\end{array}$ & $\begin{array}{l}\text { No explicit rep- } \\
\text { resentation of a } \\
\text { specific area. Ur- } \\
\text { ban region with } \\
\text { surrounding area } \\
\text { including wetlands }\end{array}$ & Extent of area & - \\
\hline & Spatial units & $\begin{array}{l}\text { No spatial resolu- } \\
\text { tion }\end{array}$ & $\begin{array}{l}\text { Size or grain of } \\
\text { grids/zones }\end{array}$ & - \\
\hline Time horizon & Time step & 1 year & $\begin{array}{l}\text { Duration of } \\
\text { model run }\end{array}$ & S: 100 years \\
\hline $\begin{array}{l}\text { Modelling ap- } \\
\text { proach }\end{array}$ & $\begin{array}{l}\text { Simulation } \\
\text { technique }\end{array}$ & System dynamics & $\begin{array}{l}\text { Qualitative or } \\
\text { quantitative }\end{array}$ & Qualitative \\
\hline \multicolumn{5}{|l|}{ Contents } \\
\hline Main purpose & \multirow{2}{*}{\multicolumn{4}{|c|}{$\begin{array}{l}\text { Assessing the impact of urban sprawl on wetland biodiversity and social welfare } \\
\text { Population growth within city } \rightarrow \text { higher population density and more need } \\
\text { for agricultural land } \rightarrow \text { expansionists attempt to buy surrounding area } \rightarrow \\
\text { change of wetland area to urban area \& more agriculture decrease wetland } \\
\text { biodiversity } \rightarrow \text { conservationists' valuation of remaining biodiversity increases } \\
\rightarrow \text { conservationists buy wetland area for nature protection }\end{array}$}} \\
\hline $\begin{array}{l}\text { Main variables } \\
\text { with relationships }\end{array}$ & & & & \\
\hline \multirow{3}{*}{$\begin{array}{l}\text { Human decision } \\
\text { making }\end{array}$} & Domain & $\begin{array}{l}\text { Human decision } \\
\text { making is rep- } \\
\text { resented within } \\
\text { system dynamics } \\
\text { equations }\end{array}$ & $\begin{array}{l}\text { Temporal } \\
\text { range }\end{array}$ & 1 year \\
\hline & $\begin{array}{l}\text { Typology } \\
\text { (classes) of } \\
\text { agents? }\end{array}$ & Yes & $\begin{array}{l}\rightarrow \text { if yes: what } \\
\text { types? }\end{array}$ & $\begin{array}{l}\text { Expansionists, con- } \\
\text { servationists (see } \\
\text { above) and owners } \\
\text { of land }\end{array}$ \\
\hline & $\begin{array}{l}\text { Decision algo- } \\
\text { rithm }\end{array}$ & $\begin{array}{l}\text { Land is sold to the } \\
\text { highest bidder }\end{array}$ & $\begin{array}{l}\text { Input into de- } \\
\text { cision }\end{array}$ & $\begin{array}{l}\text { Prices offered by } \\
\text { conservationists } \\
\text { and expansionists. }\end{array}$ \\
\hline Goals & $\begin{array}{l}\text { Authors' opin- } \\
\text { ion }\end{array}$ & \multicolumn{3}{|c|}{$\begin{array}{l}\text { First step for improving relationship between economic } \\
\text { development and biodiversity }\end{array}$} \\
\hline $\begin{array}{l}\text { Model development } \\
\text { process }\end{array}$ & Concept & Not mentioned & $\begin{array}{l}\text { Quantification } \\
\text { of relationships }\end{array}$ & Not mentioned \\
\hline
\end{tabular}


Table 12: MOLAND [CA_4]

\begin{tabular}{|c|c|c|c|c|}
\hline Name of model & \multicolumn{4}{|l|}{ MOLAND } \\
\hline Sources & \multicolumn{4}{|c|}{ Engelen et al. (2007) } \\
\hline \multicolumn{5}{|l|}{ Technical data } \\
\hline \multirow[t]{2}{*}{ Application area } & $\begin{array}{l}\text { Covered } \\
\text { area, physical } \\
\text { boundaries }\end{array}$ & $\begin{array}{l}\text { Several examples } \\
\text { across Europe and } \\
\text { elsewhere }\end{array}$ & Extent of area & User-specified \\
\hline & Spatial units & $\begin{array}{l}\text { global: } 1 \text { zone / } \\
\text { regional: zones, } \\
\text { typically NUTS / } \\
\text { local: grid cells }\end{array}$ & $\begin{array}{l}\text { Size or grain of } \\
\text { grids/zones }\end{array}$ & User-specified \\
\hline \multirow[t]{2}{*}{ Time horizon } & Time step & annual & $\begin{array}{l}\text { Duration of } \\
\text { model run }\end{array}$ & $\begin{array}{l}\text { C: last } 40-50 \\
\text { years / S: user- } \\
\text { specified, normally } \\
30 \text { years }\end{array}$ \\
\hline & $\begin{array}{l}\text { Simulation } \\
\text { technique }\end{array}$ & $\begin{array}{l}\text { Mainly rule-based } \\
\text { cellular automata }\end{array}$ & $\begin{array}{l}\text { Qualitative or } \\
\text { quantitative }\end{array}$ & Quantitative \\
\hline \multicolumn{5}{|l|}{ Contents } \\
\hline Main purpose & \multicolumn{4}{|c|}{$\begin{array}{l}\text { To monitor developments of urban areas and identify trends at the European } \\
\text { level, focus is on growth scenarios }\end{array}$} \\
\hline $\begin{array}{l}\text { Main variables } \\
\text { with relationships }\end{array}$ & \multicolumn{4}{|c|}{$\begin{array}{l}\text { Growth of economy and population (global level) } \rightarrow \text { growth in competing } \\
\text { regions (regional level), sets boundaries for all cells in a region } \rightarrow \text { rules for } \\
\text { land use change at the grid level: physical suitability, institutional suitabil- } \\
\text { ity (e.g., planning documents), accessibility (via transport network), dy- } \\
\text { namics at the local level (land use functions attracting or repelling each } \\
\text { other) } \\
\text { Feedback from grid level to regional level: spatial distribution leads to qual- } \\
\text { ity and availability of space for different activities, which influences compar- } \\
\text { ative attractiveness of a region }\end{array}$} \\
\hline \multirow{3}{*}{$\begin{array}{l}\text { Human decision } \\
\text { making }\end{array}$} & Domain & $\begin{array}{l}\text { No explicit decision } \\
\text { making }\end{array}$ & $\begin{array}{l}\text { Temporal } \\
\text { range }\end{array}$ & - \\
\hline & $\begin{array}{l}\text { Typology } \\
\text { (classes) of } \\
\text { agents? }\end{array}$ & - & $\begin{array}{l}\rightarrow \text { if yes: what } \\
\text { types? }\end{array}$ & - \\
\hline & $\begin{array}{l}\text { Decision algo- } \\
\text { rithm }\end{array}$ & - & $\begin{array}{l}\text { Input into de- } \\
\text { cision }\end{array}$ & - \\
\hline Goals & $\begin{array}{l}\text { Authors' opin- } \\
\text { ion }\end{array}$ & Achieved & & \\
\hline $\begin{array}{l}\text { Model development } \\
\text { process }\end{array}$ & Concept & Not mentioned & $\begin{array}{l}\text { Quantification } \\
\text { of relationships }\end{array}$ & $\begin{array}{l}\text { Calibration with } \\
\text { historical data }\end{array}$ \\
\hline
\end{tabular}


Table 13: PUMA (Predicting Urbanisation with Multi-Agents) [ABM_3]

\begin{tabular}{|c|c|c|c|c|}
\hline Name of model & \multicolumn{4}{|c|}{ PUMA (Predicting Urbanisation with Multi-Agents) } \\
\hline Sources & \multicolumn{4}{|c|}{ Ettema et al. (2007) } \\
\hline \multicolumn{5}{|l|}{ Technical data } \\
\hline \multirow[t]{2}{*}{ Application area } & $\begin{array}{l}\text { Covered } \\
\text { area, physical } \\
\text { boundaries }\end{array}$ & $\begin{array}{l}\text { North Dutch } \\
\text { Ranstadt (includ- } \\
\text { ing Amsterdam, } \\
\text { Utrecht, Schiphol } \\
\text { airport) }\end{array}$ & Extent of area & $\begin{array}{l}3.16 \text { million inhabi- } \\
\text { tants }\end{array}$ \\
\hline & Spatial units & $\begin{array}{l}\text { Grid cells (and } \\
\text { travel zones) }\end{array}$ & $\begin{array}{l}\text { Size or grain of } \\
\text { grids/zones }\end{array}$ & $500 \times 500 \mathrm{~m}$ \\
\hline Time horizon & Time step & $\begin{array}{l}1 \text { year / later: up } \\
\text { to daily }\end{array}$ & $\begin{array}{l}\text { Duration of } \\
\text { model run }\end{array}$ & $\begin{array}{l}\text { S: } 2000 \text { to approx. } \\
2050\end{array}$ \\
\hline $\begin{array}{l}\text { Modelling ap- } \\
\text { proach }\end{array}$ & $\begin{array}{l}\text { Simulation } \\
\text { technique }\end{array}$ & $\begin{array}{l}\text { Agent-based simu- } \\
\text { lation }\end{array}$ & $\begin{array}{l}\text { Qualitative or } \\
\text { quantitative }\end{array}$ & Quantitative \\
\hline \multicolumn{5}{|l|}{ Contents } \\
\hline Main purpose & \multicolumn{4}{|c|}{ Predicting urbanisation using behavioural agents } \\
\hline $\begin{array}{l}\text { Main variables } \\
\text { with relationships }\end{array}$ & \multicolumn{4}{|c|}{$\begin{array}{l}\text { Demographic change } \rightarrow \text { decisions of individuals } \rightarrow \text { land use change / Not yet } \\
\text { implemented: developers, authorities and firms/institutions (so far exogenous) } \\
\text { [impact of household's decisions on land use not described] }\end{array}$} \\
\hline \multirow{3}{*}{$\begin{array}{l}\text { Human decision } \\
\text { making }\end{array}$} & Domain & $\begin{array}{l}\text { 1. demographic } \\
\text { events (no deci- } \\
\text { sions, just stochas- } \\
\text { tic) } \\
\text { 2. residential } \\
\text { relocation } \\
\text { 3. job changes }\end{array}$ & $\begin{array}{l}\text { Temporal } \\
\text { range }\end{array}$ & $\begin{array}{l}\text { Annual [Daily de- } \\
\text { cisions in future } \\
\text { work] }\end{array}$ \\
\hline & $\begin{array}{l}\text { Typology } \\
\text { (classes) of } \\
\text { agents? }\end{array}$ & Yes & $\begin{array}{l}\rightarrow \text { if yes: what } \\
\text { types? }\end{array}$ & $\begin{array}{l}\text { Households: Num- } \\
\text { ber of adults and } \\
\text { children; age of } \\
\text { household head } \\
\text { [dwellings are } \\
\text { agents as well] }\end{array}$ \\
\hline & $\begin{array}{l}\text { Decision algo- } \\
\text { rithm }\end{array}$ & $\begin{array}{l}\text { Rational choice } \\
\text { with utility max- } \\
\text { imisation }\end{array}$ & $\begin{array}{l}\text { Input into de- } \\
\text { cision }\end{array}$ & $\begin{array}{l}\text { Residential relo- } \\
\text { cation: character- } \\
\text { istics of dwelling, } \\
\text { commuting dis- } \\
\text { tance, socio- } \\
\text { demographics / } \\
\text { Job choice: salary, } \\
\text { job type, dis- } \\
\text { tance to dwelling, } \\
\text { personal prefer- } \\
\text { ences... }\end{array}$ \\
\hline Goals & $\begin{array}{l}\text { Authors' opin- } \\
\text { ion }\end{array}$ & \multicolumn{3}{|c|}{ Promising approach, still work in progress } \\
\hline $\begin{array}{l}\text { Model development } \\
\text { process }\end{array}$ & Concept & Empirical data & $\begin{array}{l}\text { Quantification } \\
\text { of relationships }\end{array}$ & Empirical data \\
\hline
\end{tabular}


Table 14: Rotterdam urban dynamics [SD_4]

\begin{tabular}{|c|c|c|c|c|}
\hline Name of model & \multicolumn{4}{|c|}{ Rotterdam urban dynamics } \\
\hline Sources & \multicolumn{4}{|c|}{ Sanders and Sanders (2004) } \\
\hline \multicolumn{5}{|l|}{ Technical data } \\
\hline \multirow[t]{2}{*}{ Application area } & $\begin{array}{l}\text { Covered } \\
\text { area, physical } \\
\text { boundaries }\end{array}$ & Rotterdam & Extent of area & 100,000 acres \\
\hline & Spatial units & $\begin{array}{l}16 \text { grid cells called } \\
\text { "zones" }\end{array}$ & $\begin{array}{l}\text { Size or grain of } \\
\text { grids/zones }\end{array}$ & $\begin{array}{l}\text { Squares with } 3,125 \\
\text { miles each side }\end{array}$ \\
\hline Time horizon & Time step & & $\begin{array}{l}\text { Duration of } \\
\text { model run }\end{array}$ & S: 250 years \\
\hline $\begin{array}{l}\text { Modelling ap- } \\
\text { proach }\end{array}$ & $\begin{array}{l}\text { Simulation } \\
\text { technique }\end{array}$ & System dynamics & $\begin{array}{l}\text { Qualitative or } \\
\text { quantitative }\end{array}$ & Quantitative \\
\hline \multicolumn{5}{|l|}{ Contents } \\
\hline Main purpose & \multicolumn{4}{|c|}{$\begin{array}{l}\text { Redefining the model of urban dynamics by Forrester (1969), including: } 1 . \\
\text { spatial dimension ( } 16 \text { squares) and } 2 \text {. disaggregation: different types of hous- } \\
\text { ing, industry, and people in zones }\end{array}$} \\
\hline $\begin{array}{l}\text { Main variables } \\
\text { with relationships }\end{array}$ & \multicolumn{4}{|c|}{$\begin{array}{l}\text { Bi-directional causal loops between: population, housing availability, houses, } \\
\text { land availability, business structures, and job availability (linked with popu- } \\
\text { lation) / Two markets: labor market and housing market compete for land / } \\
\text { (no transportation) }\end{array}$} \\
\hline \multirow{3}{*}{$\begin{array}{l}\text { Human decision } \\
\text { making }\end{array}$} & Domain & $\begin{array}{l}\text { No explicit decision } \\
\text { making }\end{array}$ & $\begin{array}{l}\text { Temporal } \\
\text { range }\end{array}$ & - \\
\hline & $\begin{array}{l}\text { Typology } \\
\text { (classes) of } \\
\text { agents? }\end{array}$ & - & $\begin{array}{l}\rightarrow \text { if yes: what } \\
\text { types? }\end{array}$ & - \\
\hline & $\begin{array}{l}\text { Decision algo- } \\
\text { rithm }\end{array}$ & - & $\begin{array}{l}\text { Input into de- } \\
\text { cision }\end{array}$ & - \\
\hline Goals & $\begin{array}{l}\text { Authors' opin- } \\
\text { ion }\end{array}$ & \multicolumn{3}{|c|}{$\begin{array}{l}\text { Case of Rotterdam only as an example for generic re- } \\
\text { sults }\end{array}$} \\
\hline $\begin{array}{l}\text { Model development } \\
\text { process }\end{array}$ & Concept & Not mentioned & $\begin{array}{l}\text { Quantification } \\
\text { of relationships }\end{array}$ & $\begin{array}{l}\text { Out of statistical } \\
\text { data and expert } \\
\text { knowledge }\end{array}$ \\
\hline
\end{tabular}


Table 15: SCOPE (South Coast Outlook and Participation Experience) [SD_5]

\begin{tabular}{|c|c|c|c|c|}
\hline Name of model & \multicolumn{4}{|c|}{ SCOPE (South Coast Outlook and Participation Experience) } \\
\hline Sources & \multicolumn{4}{|c|}{ Onsted (2002) } \\
\hline \multicolumn{5}{|l|}{ Technical data } \\
\hline \multirow[t]{2}{*}{ Application area } & $\begin{array}{l}\text { Covered } \\
\text { area, physical } \\
\text { boundaries }\end{array}$ & $\begin{array}{l}\text { South Coast of } \\
\text { Santa Barbara } \\
\text { County }\end{array}$ & Extent of area & $\begin{array}{l}137,000 \text { acres / } \\
\text { Approx. 200,000 } \\
\text { inhabitants }\end{array}$ \\
\hline & Spatial units & $\begin{array}{l}\text { No spatial resolu- } \\
\text { tion }\end{array}$ & $\begin{array}{l}\text { Size or grain of } \\
\text { grids/zones }\end{array}$ & - \\
\hline Time horizon & Time step & & $\begin{array}{l}\text { Duration of } \\
\text { model run }\end{array}$ & $\begin{array}{l}\text { V: } 1960-2000 / \mathrm{S}: \\
2000-2040\end{array}$ \\
\hline $\begin{array}{l}\text { Modelling ap- } \\
\text { proach }\end{array}$ & $\begin{array}{l}\text { Simulation } \\
\text { technique }\end{array}$ & System dynamics & $\begin{array}{l}\text { Qualitative or } \\
\text { quantitative }\end{array}$ & Quantitative \\
\hline \multicolumn{5}{|l|}{ Contents } \\
\hline Main purpose & \multicolumn{4}{|c|}{$\begin{array}{l}\text { Simulation model to provide scenarios for future land use in Santa Barbara, } \\
\text { e.g., with restrictions to urban growth }\end{array}$} \\
\hline $\begin{array}{l}\text { Main variables } \\
\text { with relationships }\end{array}$ & \multicolumn{4}{|c|}{ Five sectors: housing, population, business, quality of life, land use } \\
\hline \multirow{3}{*}{$\begin{array}{l}\text { Human decision } \\
\text { making }\end{array}$} & Domain & $\begin{array}{l}\text { No explicit decision } \\
\text { making }\end{array}$ & $\begin{array}{l}\text { Temporal } \\
\text { range }\end{array}$ & - \\
\hline & $\begin{array}{l}\text { Typology } \\
\text { (classes) of } \\
\text { agents? }\end{array}$ & - & $\begin{array}{l}\rightarrow \text { if yes: what } \\
\text { types? }\end{array}$ & - \\
\hline & $\begin{array}{l}\text { Decision algo- } \\
\text { rithm }\end{array}$ & - & $\begin{array}{l}\text { Input into de- } \\
\text { cision }\end{array}$ & - \\
\hline Goals & $\begin{array}{l}\text { Authors' opin- } \\
\text { ion }\end{array}$ & \multicolumn{3}{|c|}{ Achieved, but should still become more differentiated. } \\
\hline $\begin{array}{l}\text { Model development } \\
\text { process }\end{array}$ & Concept & Expert knowledge & $\begin{array}{l}\text { Quantification } \\
\text { of relationships }\end{array}$ & $\begin{array}{l}\text { Assumptions and } \\
\text { statistical data }\end{array}$ \\
\hline
\end{tabular}


Table 16: Simulation of polycentric urban growth dynamics through agents [ABM_4]

\begin{tabular}{|c|c|c|c|c|}
\hline Name of model & \multicolumn{4}{|c|}{ Simulation of polycentric urban growth dynamics through agents } \\
\hline Sources & \multicolumn{4}{|c|}{ Loibl et al. (2007) } \\
\hline \multicolumn{5}{|l|}{ Technical data } \\
\hline \multirow[t]{2}{*}{ Application area } & $\begin{array}{l}\text { Covered } \\
\text { area, physical } \\
\text { boundaries }\end{array}$ & $\begin{array}{l}\text { Austrian Rhine } \\
\text { valley with } \\
\text { medium-sized cen- } \\
\text { tres and rural vil- } \\
\text { lages }\end{array}$ & Extent of area & $\begin{array}{l}7,330 \text { hectares } \\
\text { built-up area / } \\
260,000 \text { inhabitants }\end{array}$ \\
\hline & Spatial units & Grid cells & $\begin{array}{l}\text { Size or grain of } \\
\text { grids/zones }\end{array}$ & $50 \times 50 \mathrm{~m}$ cells \\
\hline Time horizon & Time step & $\begin{array}{l}\text { Simulation stops } \\
\text { when certain } \\
\text { household, popula- } \\
\text { tion and workplace } \\
\text { growth numbers } \\
\text { are achieved }\end{array}$ & $\begin{array}{l}\text { Duration of } \\
\text { model run }\end{array}$ & $\begin{array}{l}\text { V: } 1990-2000 / \mathrm{S}: \\
\text { user-specified }\end{array}$ \\
\hline $\begin{array}{l}\text { Modelling ap- } \\
\text { proach }\end{array}$ & $\begin{array}{l}\text { Simulation } \\
\text { technique }\end{array}$ & $\begin{array}{l}\text { Agent-based simu- } \\
\text { lation }\end{array}$ & $\begin{array}{l}\text { Qualitative or } \\
\text { quantitative }\end{array}$ & Quantitative \\
\hline \multicolumn{5}{|l|}{ Contents } \\
\hline Main purpose & \multicolumn{4}{|c|}{$\begin{array}{l}\text { Development of built-up area in peri-urban region, driven by households and } \\
\text { entrepreneurs; urban growth with different growth rates }\end{array}$} \\
\hline $\begin{array}{l}\text { Main variables } \\
\text { with relationships }\end{array}$ & \multicolumn{4}{|c|}{$\begin{array}{l}\text { Initialisation: increase of household and workplace numbers is defined } \\
\text { 1. Municipality choice depending on regional attractiveness criteria (num- } \\
\text { bers of people, households and workplaces in the start of the year, average } \\
\text { travel time to district centres and capital city, average share of attractive } \\
\text { land-use classes in the municipality (open space, forest area) } \rightarrow \text { household } \\
\text { growth and workplace growth per municipality } \rightarrow \text { transformation of abso- } \\
\text { lute values into relative search frequencies } \rightarrow \text { agents choose municipality via } \\
\text { discrete choice } \\
\text { 2. Local target area search: start with random cell, choosing most attrac- } \\
\text { tive cell } \\
\text { 3. land use change (new built-up area, higher density) } \rightarrow \text { influencing local } \\
\text { attractiveness }\end{array}$} \\
\hline \multirow{3}{*}{$\begin{array}{l}\text { Human decision } \\
\text { making }\end{array}$} & Domain & $\begin{array}{l}\text { Causing the con- } \\
\text { struction of new } \\
\text { built-up area or } \\
\text { the densifica- } \\
\text { tion of existing } \\
\text { area, no moving } \\
\text { as 'exchange' of } \\
\text { dwellings }\end{array}$ & $\begin{array}{l}\text { Temporal } \\
\text { range }\end{array}$ & $\begin{array}{l}\text { Long-term (mov- } \\
\text { ing / start-up of } \\
\text { companies) }\end{array}$ \\
\hline & $\begin{array}{l}\text { Typology } \\
\text { (classes) of } \\
\text { agents? }\end{array}$ & Yes & $\begin{array}{l}\rightarrow \text { if yes: what } \\
\text { types? }\end{array}$ & $\begin{array}{l}\text { Four household } \\
\text { types }(1,2,3 \text { or } \\
4 \text { persons) and } \\
\text { two entrepreneurs } \\
\text { (small and large) }\end{array}$ \\
\hline & $\begin{array}{l}\text { Decision algo- } \\
\text { rithm }\end{array}$ & Discrete choice & $\begin{array}{l}\text { Input into de- } \\
\text { cision }\end{array}$ & $\begin{array}{l}\text { Regional and local } \\
\text { attractiveness }\end{array}$ \\
\hline Goals & $\begin{array}{l}\text { Authors' opin- } \\
\text { ion }\end{array}$ & Achieved & & \\
\hline $\begin{array}{l}\text { Model development } \\
\text { process }\end{array}$ & Concept & Empirical data & $\begin{array}{l}\text { Quantification } \\
\text { of relationships }\end{array}$ & Empirical data \\
\hline
\end{tabular}


Table 17: SLEUTH (Slope, Landuse, Exclusion, Urban Extend, Transportation and Hillshade) [CA_5]

\begin{tabular}{|c|c|c|c|c|}
\hline Name of model & \multicolumn{4}{|c|}{$\begin{array}{l}\text { SLEUTH (Slope, Landuse, Exclusion, Urban Extend, Transportation and Hill- } \\
\text { shade) }\end{array}$} \\
\hline Sources & \multicolumn{4}{|c|}{ Clarke et al. (1997); Silva and Clarke (2002); Dietzel and Clarke (2007) } \\
\hline \multicolumn{5}{|l|}{ Technical data } \\
\hline \multirow[t]{2}{*}{ Application area } & $\begin{array}{l}\text { Covered } \\
\text { area, physical } \\
\text { boundaries }\end{array}$ & $\begin{array}{l}\text { Numerous applica- } \\
\text { tions, mostly U.S. }\end{array}$ & Extent of area & User-specified \\
\hline & Spatial units & Grid cells & $\begin{array}{l}\text { Size or grain of } \\
\text { grids/zones }\end{array}$ & $\begin{array}{l}\text { Input for model: } \\
8 \text {-bit GIF } \\
(100 \times 100 \mathrm{~m} \text { cells } \\
\text { can be converted })\end{array}$ \\
\hline Time horizon & Time step & 1 year & $\begin{array}{l}\text { Duration of } \\
\text { model run }\end{array}$ & $\begin{array}{l}\text { C: at least } 4 \text { time } \\
\text { steps / S: User- } \\
\text { specified }\end{array}$ \\
\hline $\begin{array}{l}\text { Modelling ap- } \\
\text { proach }\end{array}$ & $\begin{array}{l}\text { Simulation } \\
\text { technique }\end{array}$ & Cellular automata & $\begin{array}{l}\text { Qualitative or } \\
\text { quantitative }\end{array}$ & Quantitative \\
\hline \multicolumn{5}{|l|}{ Contents } \\
\hline Main purpose & \multicolumn{4}{|c|}{ Modelling urban growth, scenarios for future development of an urban region } \\
\hline $\begin{array}{l}\text { Main variables } \\
\text { with relationships }\end{array}$ & \multicolumn{4}{|c|}{$\begin{array}{l}\text { Two components (use depends on available data): } \\
\text { (1) Urban growth: cells have one of two states: urban or non urban } \\
\text { (2) Urban land use change with different land-use types } \\
\text { Four types of growth behaviour: spontaneous, diffusive (with new growth } \\
\text { centres), organic (into surroundings) and road-influenced } \\
\text { Five main coefficients: diffusion, breed, spread, slope, and road coefficient } \\
\text { (need to be calibrated for each case study) } \\
\text { Self modification rules: e.g., concerning the kind of exponential or S-curve } \\
\text { growth; denser road network } \rightarrow \text { road gravity factor increases; land avail- } \\
\text { ability decreases } \rightarrow \text { slope resistance factor is decreased (more hilly areas); } \\
\text { spread factor increases over time }\end{array}$} \\
\hline \multirow{3}{*}{$\begin{array}{l}\text { Human decision } \\
\text { making }\end{array}$} & Domain & $\begin{array}{l}\text { No explicit decision } \\
\text { making }\end{array}$ & $\begin{array}{l}\text { Temporal } \\
\text { range }\end{array}$ & - \\
\hline & $\begin{array}{l}\text { Typology } \\
\text { (classes) of } \\
\text { agents? }\end{array}$ & - & $\begin{array}{l}\rightarrow \text { if yes: what } \\
\text { types? }\end{array}$ & - \\
\hline & $\begin{array}{l}\text { Decision algo- } \\
\text { rithm }\end{array}$ & - & $\begin{array}{l}\text { Input into de- } \\
\text { cision }\end{array}$ & - \\
\hline Goals & $\begin{array}{l}\text { Authors' opin- } \\
\text { ion }\end{array}$ & Achieved & & \\
\hline $\begin{array}{l}\text { Model development } \\
\text { process }\end{array}$ & Concept & Not mentioned & $\begin{array}{l}\text { Quantification } \\
\text { of relationships }\end{array}$ & $\begin{array}{l}\text { Calibration using } \\
\text { historical maps }\end{array}$ \\
\hline
\end{tabular}


Table 18: Urban dynamics [SD_1]

\begin{tabular}{|c|c|c|c|c|}
\hline Name of model & \multicolumn{4}{|l|}{ Urban dynamics } \\
\hline Sources & \multicolumn{4}{|c|}{ Forrester (1969); Alfeld (1995) } \\
\hline \multicolumn{5}{|l|}{ Technical data } \\
\hline \multirow[t]{2}{*}{ Application area } & $\begin{array}{l}\text { Covered } \\
\text { area, physical } \\
\text { boundaries }\end{array}$ & $\begin{array}{l}\text { Either suburban or } \\
\text { core area (Forrester } \\
\text { 1969: 2) / Exam- } \\
\text { ples mentioned in } \\
\text { Alfeld, 1995: Low- } \\
\text { ell, Boston, Con- } \\
\text { cord, Marlborough, } \\
\text { Palm Coast }\end{array}$ & Extent of area & User-specified \\
\hline & Spatial units & $\begin{array}{l}\text { No spatial resolu- } \\
\text { tion }\end{array}$ & $\begin{array}{l}\text { Size or grain of } \\
\text { grids/zones }\end{array}$ & - \\
\hline Time horizon & Time step & & $\begin{array}{l}\text { Duration of } \\
\text { model run }\end{array}$ & S: Up to 250 years \\
\hline $\begin{array}{l}\text { Modelling ap- } \\
\text { proach }\end{array}$ & $\begin{array}{l}\text { Simulation } \\
\text { technique }\end{array}$ & System dynamics & $\begin{array}{l}\text { Qualitative or } \\
\text { quantitative }\end{array}$ & Quantitative \\
\hline \multicolumn{5}{|l|}{ Contents } \\
\hline Main purpose & \multicolumn{4}{|c|}{$\begin{array}{l}\text { Modelling urban system in general, explicitly including "urban decline." Ex- } \\
\text { amples: focus on a specific topic, e.g., rapid population growth, demolition, et } \\
\text { cetera, and therefore need specific models. }\end{array}$} \\
\hline $\begin{array}{l}\text { Main variables } \\
\text { with relationships }\end{array}$ & \multicolumn{4}{|c|}{ Original model by Forrester: Three subsystems: business, housing, population } \\
\hline \multirow{3}{*}{$\begin{array}{l}\text { Human decision } \\
\text { making }\end{array}$} & Domain & $\begin{array}{l}\text { No explicit decision } \\
\text { making }\end{array}$ & $\begin{array}{l}\text { Temporal } \\
\text { range }\end{array}$ & - \\
\hline & $\begin{array}{l}\text { Typology } \\
\text { (classes) of } \\
\text { agents? }\end{array}$ & - & $\begin{array}{l}\rightarrow \text { if yes: what } \\
\text { types? }\end{array}$ & - \\
\hline & $\begin{array}{l}\text { Decision algo- } \\
\text { rithm }\end{array}$ & - & $\begin{array}{l}\text { Input into de- } \\
\text { cision }\end{array}$ & - \\
\hline Goals & $\begin{array}{l}\text { Authors' opin- } \\
\text { ion }\end{array}$ & Achieved & & \\
\hline $\begin{array}{l}\text { Model development } \\
\text { process }\end{array}$ & Concept & Expert knowledge & $\begin{array}{l}\text { Quantification } \\
\text { of relationships }\end{array}$ & $\begin{array}{l}\text { Statistical data } \\
\text { and own estimation }\end{array}$ \\
\hline
\end{tabular}


Table 19: Urban transformation process in the Haaglanden region [SD_6]

\begin{tabular}{|c|c|c|c|c|}
\hline Name of model & \multicolumn{4}{|c|}{$\begin{array}{l}\text { Simulating the urban transformation process in the Haaglanden region in the } \\
\text { Netherlands }\end{array}$} \\
\hline Sources & \multicolumn{4}{|c|}{ Eskinasi and Rouwette (2004) } \\
\hline \multicolumn{5}{|l|}{ Technical data } \\
\hline \multirow[t]{2}{*}{ Application area } & $\begin{array}{l}\text { Covered } \\
\text { area, physical } \\
\text { boundaries }\end{array}$ & $\begin{array}{l}\text { The Haaglanden } \\
\text { region, including } \\
\text { the Hague and sur- } \\
\text { rounding suburbs }\end{array}$ & Extent of area & \\
\hline & Spatial units & $\begin{array}{l}\text { No spatial resolu- } \\
\text { tion }\end{array}$ & $\begin{array}{l}\text { Size or grain of } \\
\text { grids/zones }\end{array}$ & - \\
\hline Time horizon & Time step & & $\begin{array}{l}\text { Duration of } \\
\text { model run }\end{array}$ & S: $1998-2010$ \\
\hline $\begin{array}{l}\text { Modelling ap- } \\
\text { proach }\end{array}$ & $\begin{array}{l}\text { Simulation } \\
\text { technique }\end{array}$ & System dynamics & $\begin{array}{l}\text { Qualitative or } \\
\text { quantitative }\end{array}$ & Qualitative \\
\hline \multicolumn{5}{|l|}{ Contents } \\
\hline Main purpose & \multicolumn{4}{|c|}{$\begin{array}{l}\text { Assessing the impact of future policy interventions on the social housing mar- } \\
\text { ket (specific: rate of building new dwellings) }\end{array}$} \\
\hline $\begin{array}{l}\text { Main variables } \\
\text { with relationships }\end{array}$ & \multicolumn{4}{|c|}{$\begin{array}{l}\text { Four stocks: } \\
1 \text { Commercial housing stock } \\
2 \text { Social housing stock } \\
3 \text { Waiting families } \\
4 \text { Supply of available social houses } \\
\text { Processes involved: Migration, demolition, construction }\end{array}$} \\
\hline \multirow{3}{*}{$\begin{array}{l}\text { Human decision } \\
\text { making }\end{array}$} & Domain & $\begin{array}{l}\text { No explicit decision } \\
\text { making }\end{array}$ & $\begin{array}{l}\text { Temporal } \\
\text { range }\end{array}$ & - \\
\hline & $\begin{array}{l}\text { Typology } \\
\text { (classes) of } \\
\text { agents? }\end{array}$ & - & $\begin{array}{l}\rightarrow \text { if yes: what } \\
\text { types? }\end{array}$ & - \\
\hline & $\begin{array}{l}\text { Decision algo- } \\
\text { rithm }\end{array}$ & - & $\begin{array}{l}\text { Input into de- } \\
\text { cision }\end{array}$ & - \\
\hline \multirow[t]{2}{*}{ Goals } & $\begin{array}{l}\text { Authors' opin- } \\
\text { ion }\end{array}$ & \multicolumn{3}{|c|}{ Model is useful for its goal } \\
\hline & Validation & $\begin{array}{l}\text { No (but impact of } \\
\text { process on stake- } \\
\text { holders is moni- } \\
\text { tored) }\end{array}$ & $\begin{array}{l}\text { Plausibility } \\
\text { analysis }\end{array}$ & With stakeholders \\
\hline $\begin{array}{l}\text { Model development } \\
\text { process }\end{array}$ & Concept & $\begin{array}{l}\text { Participation of } \\
\text { stakeholders, nar- } \\
\text { rative approach }\end{array}$ & $\begin{array}{l}\text { Quantification } \\
\text { of relationships }\end{array}$ & $\begin{array}{l}\text { Empirical data or } \\
\text { expert guesses. }\end{array}$ \\
\hline
\end{tabular}


Table 20: Urban travel system [SD_7]

\begin{tabular}{|c|c|c|c|c|}
\hline Name of model & \multicolumn{4}{|c|}{ A system dynamics model for the urban travel system } \\
\hline Sources & \multicolumn{4}{|l|}{ Raux (2003) } \\
\hline \multicolumn{5}{|l|}{ Technical data } \\
\hline \multirow[t]{2}{*}{ Application area } & $\begin{array}{l}\text { Covered } \\
\text { area, physical } \\
\text { boundaries }\end{array}$ & Hypothetical city & Extent of area & - \\
\hline & Spatial units & $\begin{array}{l}\text { No spatial resolu- } \\
\text { tion }\end{array}$ & $\begin{array}{l}\text { Size or grain of } \\
\text { grids/zones }\end{array}$ & - \\
\hline Time horizon & Time step & & $\begin{array}{l}\text { Duration of } \\
\text { model run }\end{array}$ & $\begin{array}{l}\text { S: } 20 \text { years into the } \\
\text { future }\end{array}$ \\
\hline $\begin{array}{l}\text { Modelling ap- } \\
\text { proach }\end{array}$ & $\begin{array}{l}\text { Simulation } \\
\text { technique }\end{array}$ & System dynamics & $\begin{array}{l}\text { Qualitative or } \\
\text { quantitative }\end{array}$ & Quantitative \\
\hline \multicolumn{5}{|l|}{ Contents } \\
\hline Main purpose & \multicolumn{4}{|c|}{$\begin{array}{l}\text { To simulate medium- and long-term effects of urban transport policies with } \\
\text { reference to sustainable travel }\end{array}$} \\
\hline $\begin{array}{l}\text { Main variables } \\
\text { with relationships }\end{array}$ & \multicolumn{4}{|c|}{$\begin{array}{l}\text { Seven major blocks: urbanisation, internal travel demand (trips within } \\
\text { system), car ownership, external travel demand (inflowing, outflowing and } \\
\text { through traffic), transportation (comparing supply and demand) and evalua- } \\
\text { tion (socioeconomic and environmental appraisals) }\end{array}$} \\
\hline \multirow{3}{*}{$\begin{array}{l}\text { Human decision } \\
\text { making }\end{array}$} & Domain & $\begin{array}{l}\text { No explicit decision } \\
\text { making }\end{array}$ & $\begin{array}{l}\text { Temporal } \\
\text { range }\end{array}$ & - \\
\hline & $\begin{array}{l}\text { Typology } \\
\text { (classes) of } \\
\text { agents? }\end{array}$ & - & $\begin{array}{l}\rightarrow \text { if yes: what } \\
\text { types? }\end{array}$ & - \\
\hline & $\begin{array}{l}\text { Decision algo- } \\
\text { rithm }\end{array}$ & - & $\begin{array}{l}\text { Input into de- } \\
\text { cision }\end{array}$ & - \\
\hline Goals & $\begin{array}{l}\text { Authors' opin- } \\
\text { ion }\end{array}$ & \multicolumn{3}{|l|}{ Work in progress } \\
\hline $\begin{array}{l}\text { Model development } \\
\text { process }\end{array}$ & Concept & Expert knowledge & $\begin{array}{l}\text { Quantification } \\
\text { of relationships }\end{array}$ & $\begin{array}{l}\text { Expert knowledge } \\
\text { and statistical val- } \\
\text { ues }\end{array}$ \\
\hline
\end{tabular}


Table 21: UrbanSim [ABM_5]

\begin{tabular}{|c|c|c|c|c|}
\hline Name of model & \multicolumn{4}{|l|}{ UrbanSim } \\
\hline Sources & \multicolumn{4}{|c|}{ Waddell (2006); Waddell et al. (2003) } \\
\hline \multicolumn{5}{|l|}{ Technical data } \\
\hline \multirow[t]{2}{*}{ Application area } & $\begin{array}{l}\text { Covered } \\
\text { area, physical } \\
\text { boundaries }\end{array}$ & $\begin{array}{l}\text { Several examples } \\
\text { in the U.S., Europe } \\
\text { and Asia }\end{array}$ & Extent of area & User-specified \\
\hline & Spatial units & $\begin{array}{l}\text { Initially: mix- } \\
\text { ture of parcels and } \\
\text { zones / later: grid }\end{array}$ & $\begin{array}{l}\text { Size or grain of } \\
\text { grids/zones }\end{array}$ & $\begin{array}{l}\text { User-specified / } \\
\text { Cell: } 150 \times 150 \mathrm{~m} \\
\text { regarded as default }\end{array}$ \\
\hline Time horizon & Time step & 1 year & $\begin{array}{l}\text { Duration of } \\
\text { model run }\end{array}$ & User-specified \\
\hline $\begin{array}{l}\text { Modelling ap- } \\
\text { proach }\end{array}$ & $\begin{array}{l}\text { Simulation } \\
\text { technique }\end{array}$ & $\begin{array}{l}\text { Coupled simulation } \\
\text { models including } \\
\text { agent-based simu- } \\
\text { lations }\end{array}$ & $\begin{array}{l}\text { Qualitative or } \\
\text { quantitative }\end{array}$ & Quantitative \\
\hline \multicolumn{5}{|l|}{ Contents } \\
\hline Main purpose & \multicolumn{4}{|c|}{$\begin{array}{l}\text { Link between transportation and land use; impact of different planning strate- } \\
\text { gies }\end{array}$} \\
\hline $\begin{array}{l}\text { Main variables } \\
\text { with relationships }\end{array}$ & \multicolumn{4}{|c|}{$\begin{array}{l}\text { Exogenous: (1) macroeconomics (population, employment) and (2) travel } \\
\text { demand (travel conditions). Six models: } \\
1 \text { Accessibility (output: access to workplaces and shops for each cell) } \\
2 \text { Transition (output: number of new jobs and new households per year) } \\
3 \text { Mobility (output: number of moving (existing) jobs / households) } \\
4 \text { Location (output: location of new or moving jobs / households) } \\
5 \text { Real Estate Development (output: land use change) } \\
6 \text { Land price (output: land prices) }\end{array}$} \\
\hline \multirow{3}{*}{$\begin{array}{l}\text { Human decision } \\
\text { making }\end{array}$} & Domain & $\begin{array}{l}\text { Mobility and loca- } \\
\text { tion }\end{array}$ & $\begin{array}{l}\text { Temporal } \\
\text { range }\end{array}$ & Depends on issues \\
\hline & $\begin{array}{l}\text { Typology } \\
\text { (classes) of } \\
\text { agents? }\end{array}$ & $\begin{array}{l}\text { Initially households } \\
\text { / firms, later per- } \\
\text { sons / jobs }\end{array}$ & $\begin{array}{l}\rightarrow \text { if yes: what } \\
\text { types? }\end{array}$ & User-specified \\
\hline & $\begin{array}{l}\text { Decision algo- } \\
\text { rithm }\end{array}$ & $\begin{array}{l}\text { Multinomial logit } \\
\text { model }\end{array}$ & $\begin{array}{l}\text { Input into de- } \\
\text { cision }\end{array}$ & $\begin{array}{l}\text { Land-use it- } \\
\text { self, socio- } \\
\text { demographics, } \\
\text { dwellings }\end{array}$ \\
\hline Goals & $\begin{array}{l}\text { Authors' opin- } \\
\text { ion }\end{array}$ & Achieved & & \\
\hline $\begin{array}{l}\text { Model development } \\
\text { process }\end{array}$ & Concept & Not mentioned & $\begin{array}{l}\text { Quantification } \\
\text { of relationships }\end{array}$ & $\begin{array}{l}\text { Out of empirical } \\
\text { data }\end{array}$ \\
\hline
\end{tabular}




\section{References}

Agarwal, C., Green, G.M., Grove, J.M., Evans, T.P., Schweik, C.M. (2002), "A Review and Assessment of Land-Use Change Models: Dynamics of Space, Time, and Human Choice", Gen. Tech. Rep., NE-297, Newton Square, PA (USDA, Forest Service, Northern Research Station). Related online version (cited on 2 April 2009): http://nrs.fs.fed.us/pubs/gtr/gtr_ne297.pdf. 1.3

Alberti, M. (1999), "Urban Patterns and Environmental Performance: What Do We Know?", Journal of Planning Education and Research, 19(2): 151-163, doi:10.1177/0739456X9901900205. 1.1

Alberti, M. (2008), "Modeling the Urban Ecosystem: A Conceptual Framework", in Urban Ecology: An International Perspective on the Interaction Bewteen Humans and Nature, (Eds.) Marzluff, J.M., Shulenberger, E., Endlicher, W., Alberti, M., Bradley, G., Ryan, C., Simon, U., ZumBrunnen, C., New York (Springer), doi:10.1007/978-0-387-73412-5_41. 1.3

Alfeld, L.E. (1995), "Urban dynamics - The first fifty years", System Dynamics Review, 11(3): 199-217, doi:10.1002/sdr.4260110303. 1, 18

Antrop, M. (2004), "Landscape change and the urbanization process in Europe", Landscape and Urban Planning, 67(1-4): 9-26, doi:10.1016/S0169-2046(03)00026-4. 1.1

Axhausen, K.W. (2006), "Neue Modellansätze der Verkehrsnachfragesimulation: Entwicklungslinien, Stand der Forschung, Forschungsperspektiven", in Integrierte Mikro-Simulation von Raumund Verkehrsentwicklung: Theorie, Konzepte, Modelle, Praxis, (Ed.) Beckmann, K.J., Tagungsband des 9. Aachener Kolloquium 'Mobilität und Stadt' (AMUS 2006), 18-19 September 2006, vol. 81 of Schriftenreihe Stadt Region Land, pp. 149-163, Aachen (RWTH). Related online version (cited on 8 April 2009):

http://e-collection.ethbib.ethz.ch/view/eth:28951. 1.3

Barredo, J.I., Kasanko, M., McCormick, N., Lavalle, C. (2003), "Modelling dynamic spatial processes: Simulation of urban future scenarios through cellular automata", Landscape and Urban Planning, 64(3): 145-160, doi:10.1016/S0169-2046(02)00218-9. 4

Batty, M. (2008), "The Size, Scale, and Shape of Cities", Science, 319: 769-771, doi: 10.1126/science.1151419. 1.1

Batty, M., Besussi, E., Chin, N. (2003), "Traffic, Urban Growth and Suburban Sprawl", CASA Working Papers Series, 70, London (University College London). Related online version (cited on 2 April 2009):

http://www.casa.ucl.ac.uk/working_papers/paper70.pdf. 1.1

Beckmann, K.J. (2006), "Mikro-Simulation von Raum- und Verkehrsentwicklung - Stand der Kunst und Perspektiven zwischen Forschung, Entwicklung und Praxis", in Integrierte Mikro-Simulation von Raum- und Verkehrsentwicklung: Theorie, Konzepte, Modelle, Praxis, (Ed.) Beckmann, K.J., Tagungsband des 9. Aachener Kolloquium 'Mobilität und Stadt' (AMUS 2006), 18-19 September 2006, vol. 81 of Schriftenreihe Stadt Region Land, pp. 1-31, Aachen (RWTH). 1.3

Berling-Wolff, S., Wu, J.G. (2004), "Modeling urban landscape dynamics: A review", Ecological Research, 19(1): 119-129, doi:10.1111/j.1440-1703.2003.00611.x. 1.3

Bürgi, M., Hersperger, A.M., Schneeberger, N. (2004), "Driving forces of landscape change current and new directions", Landscape Ecology, 19(8): 857-868, doi:10.1007/s10980-004-02458. 1.2 
Clarke, K.C., Hoppen, S., Gaydos, L. (1997), "A self-modifying cellular automaton model of historical urbanization in the San Francisco Bay area", Environment and Planning B: Planning and Design, 24(2): 247-261, doi:10.1068/b240247. 3, 17

Couclelis, H. (1997), "From cellular automata to urban models: new principles for model development and implementation", Environment and Planning B: Planning and Design, 24(2): 165-174, doi:10.1068/b240165. 1.2

Curran, S.R., de Sherbinin, A. (2004), "Completing the Picture: The Challenges of Bringing 'Consumption' into the Population-Environment Equation", Population and Environment, 26 (2): 107-131, doi:10.1007/s11111-004-0837-x. 1.1

de Groot, R.S., Wilson, M.A., Boumans, R.M.J. (2002), "A typology for the classification, description and valuation of ecosystem functions, goods and services", Ecological Economics, 41 (3): 393-408, doi:10.1016/S0921-8009(02)00089-7. 1.1

Dietzel, C., Clarke, K.C. (2007), "Toward Optimal Calibration of the SLEUTH Land Use Change Model", Transactions in GIS, 11(1): 29-45, doi:10.1111/j.1467-9671.2007.01031.x. 3, 1, 17

EEA (2006), "Urban sprawl in Europ: The ignored challenge", EEA Report, 10, Copenhagen (European Environmental Agency). Related online version (cited on 2 April 2009):

http://www.eea.europa.eu/publications/eea_report_2006_10. 1.1

Engelen, G., Lavalle, C., Barredo, J.I., van der Meulen, M., White, R. (2007), "The Moland Modelling Framework for Urban and Regional Land-use Dynamics", in Modelling Land-Use Change, Progress and Applications, (Eds.) Koomen, E., Stillwell, J., Bakema, A., Scholten, H.J., pp. 297-319, Dordrecht (Springer), doi:10.1007/978-1-4020-5648-2. 3, 1, 4, 12

Eppink, F.V., van den Bergh, J.C.J.M., Rietveld, P. (2004), "Modelling biodiversity and land use: urban growth, agriculture and nature in a wetland area", Ecological Economics, 51(3-4): 201-216, doi:10.1016/j.ecolecon.2004.04.011. 3, 1, 11

Eskinasi, M., Rouwette, E. (2004), "Simulating the urban transformation process in the Haaglanden region, the Netherlands", in System Dynamics Conference Proceedings (CD-ROM), (Eds.) Kennedy, M., Winch, G.W., Langer, R.S., Rowe, J.I., Yanni, J.M., 22nd International System Dynamics Conference, held in Oxford, England, July 25-29, 2004, Albany, NY (System Dynamics Society). Related online version (cited on 2 April 2009):

http://www.systemdynamics.org/conferences/2004/index.htm. 3, 1, 19

Ettema, D., de Jong, K., Timmermans, H.J.P., Bakema, A. (2007), "PUMA: Multi-Agent Modelling of Urban Systems", in Modelling Land-Use Change, Progress and Applications, (Eds.) Koomen, E., Stillwell, J., Bakema, A., Scholten, H.J., pp. 237-258, Dordrecht (Springer), doi: 10.1007/978-1-4020-5648-2. 3, 1, 13

Forrester, J.W. (1969), Urban Dynamics, Cambridge, MA (MIT Press). 3, 1, 14, 18

Geist, H.J., Lambin, E.F. (2002), "Proximate Causes and Underlying Driving Forces of Tropical Deforestation", BioScience, 52(2): 143-150, doi:10.1641/00063568(2002)052[0143:PCAUDF]2.0.CO;2. 5

Geist, H.J., Lambin, E.F. (2004), "Dynamic Causal Patterns of Desertification", BioScience, 54 (9): 817-829, doi:10.1641/0006-3568(2004)054[0817:DCPOD]2.0.CO;2. 5 
Geurs, K.T., van Wee, B. (2004), "Land-use/transport Interaction Models as Tools for Sustainability Impact Assessment of Transport Investments: Review and Research Perspectives", European Journal of Transport and Infrastructure Research, 4(3): 333-355. URL (cited on 8 April 2009): http://www.ejtir.tbm.tudelft.nl/issues/2004_03/pdf/2004_03_05.pdf. 1.3

Haase, D., Haase, A. (2008), "Do European social science data serve to feed agent-based simulation models on residential mobility in shrinking cities?", in Europe and its Regions: The Usage of European Regionalised Social Science Data, (Eds.) Grözinger, G., Matiaske, W., Spieß, C.K., pp. 227-250, Newcastle (Cambridge Scholars Publishing). 5

Haase, D., Nuissl, H. (2007), "Does urban sprawl drive changes in the water balance and policy?: The case of Leipzig (Germany) 1870-2003", Landscape and Urban Planning, 80(1-2): 1-13, doi:10.1016/j.landurbplan.2006.03.011. 5

Haghani, A., Lee, S.Y., Byun, J.H. (2003a), "A System Dynamics Approach to Land Use / Transportation System Performance Modeling, Part I: Methodology", Journal of Advanced Transportation, 37(1): 1-41. 3, 1, 5

Haghani, A., Lee, S.Y., Byun, J.H. (2003b), "A System Dynamics Approach to Land Use / Transportation System Performance Modeling, Part II: Application", Journal of Advanced Transportation, 37(1): 43-82. 3, 1, 5

Hansen, H.S. (2007), "An Adaptive Land-use Simulation Model for Integrated Coastal Zone Planning", in The European Information Society. Leading the Way with GEO-information, (Eds.) Fabrikant, S.I., Wachowicz, M., 10th Conference of the Association of Geographic Information Laboratories for Europe (AGILE), held in Aalborg, Denmark, May 8-11 2007, Lecture Notes in Geoinformation and Cartography, pp. 35-53, doi:10.1007/978-3-540-72385-1, Berlin; New York (Springer). 4

Heinrichs, D., Kabisch, S. (2006), "Risikolebensraum Megacity: Strategien für eine nachhaltige Entwicklung in Megastädten und Ballungszentren", GAIA, 15(2): 157-159. 1.1

Hunt, J.D., Kriger, D.S., Miller, E.J. (2005), "Current Operational Urban Land-useTransport Modelling Frameworks: A Review", Transport Reviews, 25(3): 329-376, doi: 10.1080/0144164052000336470. 1.2, 1.3

Iacono, M., Levinson, D., El-Geneidy, A. (2008), "Models of Transportation and Land Use Change: A Guide to the Territory", Journal of Planning Literature, 22(4): 323-340, doi: 10.1177/0885412207314010. 1.3

Johnson, M.P. (2001), "Environmental impacts of urban sprawl: a survey of the literature and proposed research agenda", Environment and Planning A, 33(4): 717-735, doi:10.1068/a3327. 1.1

Kasanko, M., Barredo, J.I., Lavalle, C., McCormick, N., Demicheli, L., Sagris, V., Brezger, A. (2006), "Are European cities becoming dispersed?: A comparative analysis of 15 European urban areas", Landscape and Urban Planning, 77(1-2): 111-130, doi: 10.1016/j.landurbplan.2005.02.003. 1.1

Lambin, E.F., Geist, H.J. (Eds.) (2006), Land-Use and Land-Cover Change: Local Processes, Global Impacts, Global Change - The IGBP Series, Berlin (Springer). 1.1

Landis, J.D., Zhang, M. (1998a), "The second generation of the California urban futures model. Part 1: Model logic and theory", Environment and Planning B: Planning and Design, 25(5): 657-666, doi:10.1068/b250657. 3, 1, 7

Living Reviews in Landscape Research

http://www. livingreviews.org/lrlr-2009-2 
Landis, J.D., Zhang, M. (1998b), "The second generation of the California urban futures model. Part 2: Specification and calibration results of the land-use change submodel", Environment and Planning B: Planning and Design, 25(6): 795-824, doi:10.1068/b250795. 3, 1, 7

Landis, J.D., Monzon, J.P., Reilly, M., Cogan, C. (1998), Development and Pilot Application of the California Urban and Biodiversity Analysis (CURBA) Model, Berkeley (University of California at Berkeley). Related online version (cited on 2 April 2009):

http://iurd.berkeley.edu/sites/default/files/pubs/MG98-01.pdf. 3, 1, 8

Liu, J., Dietz, T., Carpenter, S.R., Alberti, M., Folke, C., Moran, E., Pell, A.N., Deadman, P., Kratz, T., Lubchenko, J., Ostrom, E., Quyang, Z., Provencher, W., Redman, C.L., Schneider, S.H., Taylor, W.W. (2007), "Complexity of Coupled Human and Natural Systems", Science, 317: 1513-1516, doi:10.1126/science.1144004. 1.1, 2

Loibl, W., Tötzer, T., Köstl, M., Steinnocher, K. (2007), "Simulation of Polycentric Urban Growth Dynamics Through Agents", in Modelling Land-Use Change, Progress and Applications, (Eds.) Koomen, E., Stillwell, J., Bakema, A., Scholten, H.J., pp. 219-235, Dordrecht (Springer), doi: 10.1007/978-1-4020-5648-2. 3, 1, 16

Lutz, W., Sanderson, W., Scherbov, S. (2001), "The end of world population growth", Nature, 412: 543-545, doi:10.1038/35087589. 1.1

Mankiw, N.G., Weil, D.N. (1989), "The baby boom, the baby bust, and the housing market", Regional Science and Urban Economics, 19(2): 235-258, doi:10.1016/0166-0462(89)90005-7. 3, 1,4

Millennium Ecosystem Assessment (2005), "Ecosystems and Human Well-being: Synthesis", MA Synthesis Reports, Washington, DC (Island Press). Related online version (cited on 2 April 2009):

http://www.millenniumassessment.org/en/synthesis.aspx. 1.1

Miller, E.J., Hunt, J.D., Abraham, J.E., Salvini, P.A. (2004), "Microsimulating urban systems", Computers, Environment and Urban Systems, 28(1-2): 9-44, doi:10.1016/S0198-9715(02)000443. $1.2,1,10$

Moeckel, R., Schwarze, B., Wegener, M. (2006), "Das Projekt ILUMASS - Mikrosimulation der räumlichen, demografischen und wirtschaftlichen Entwicklung", in Integrierte Mikro-Simulation von Raum- und Verkehrsentwicklung: Theorie, Konzepte, Modelle, Praxis, (Ed.) Beckmann, K.J., Tagungsband des 9. Aachener Kolloquium 'Mobilität und Stadt' (AMUS 2006), 18-19 September 2008, vol. 81 of Schriftenreihe Stadt Region Land, pp. 53-61, Aachen (RWTH). 1, 9

Nijkamp, P., Van Wissen, L., Rima, A. (1993), "A Household Life Cycle Model for Residential Relocation Behaviour", Socio-Economic Planning Sciences, 27(1): 35-53, doi:10.1016/00380121(93)90027-G. 3, 1, 4.5, 3

Nuissl, H., Haase, D., Lanzendorf, M., Wittmer, H. (2008), "Environmental impact assessment of urban land use transitions - A context-sensitive approach", Land Use Policy, 26(2): 414-424, doi:10.1016/j.landusepol.2008.05.006. 1.1

Onsted, J.A. (2002), SCOPE: A Modification and Application of the Forrester Model to the South Coast of Santa Barbara County, Master's Thesis, University of California Santa Barbara, Santa Barbara. 3, 1, 15 
Parker, D.C., Manson, S.M., Janssen, M.A., Hoffmann, M.J., Deadman, P. (2003), "Multi-Agent Systems for the Simulation of Land-Use and Land-Cover Change: A Review", Annals of the Association of American Geographers, 93(2): 314-337, doi:10.1111/1467-8306.9302004. 3

PRB (2007), "2007 World Population Data Sheet", Washington, DC (Population Reference Bureau). Related online version (cited on 2 April 2009):

http://www.prb.org/Publications/Datasheets/2007/2007WorldPopulationDataSheet. aspx. 1.1

Ramankutty, N., Graumlich, L., Achard, F., Alves, D., Chhabra, A., DeFries, R., Foley, J.A., Geist, H.J., Houghton, R., Klein Goldewijk, K., Lambin, E., Millington, A., Rasmussen, K., Reid, R., Turner II, B.L. (2006), "Global land cover change: recent progress, remaining challenges", in Land-Use and Land-Cover Change, (Eds.) Lambin, E.F., Geist, H.J., pp. 9-39, Berlin; New York (Springer). 1.1

Raux, C. (2003), "A systems dynamics model for the urban travel system", in European Transport Conference 2003, Proceedings of ETC 2003, 8-10 October 2003, Strasbourg (CD-ROM), London (Association for European Transport). Related online version (cited on 2 April 2009): http://halshs.archives-ouvertes.fr/halshs-00092186/en/. 3, 1, 20

Ravetz, J. (2000), City Region 2020: Integrated Planning for a Sustainable Environment, London (Earthscan). 1.1

Salvini, P.A., Miller, E.J. (2005), "ILUTE: An Operational Prototype of a Comprehensive Microsimulation Model of Urban Systems", Networks and Spatial Economics, 5(2): 217-234, doi: $10.1007 / \mathrm{s} 11067-005-2630-5.3,1,10$

Sanders, P., Sanders, F. (2004), "Spatial urban dynamics. A vision on the future of urban dynamics: Forrester revisited", in System Dynamics Conference Proceedings (CD-ROM), (Eds.) Kennedy, M., Winch, G.W., Langer, R.S., Rowe, J.I., Yanni, J.M., 22nd International System Dynamics Conference, held in Oxford, England, July 25 - 29, 2004, Albany, NY (System Dynamics Society). Related online version (cited on 2 April 2009):

http://www.systemdynamics.org/conferences/2004/index.htm. 3, 1, 14

Schaldach, R., Priess, J.A. (2008), "Integrated Models of the Land System: A Review of Modelling Approaches on the Regional to Global Scale", Living Rev. Landscape Res., 2(1). URL (cited on 2 April 2009):

http://www.livingreviews.org/lrlr-2008-1. 1.3

Silva, E.A., Clarke, K.C. (2002), "Calibration of the SLEUTH urban growth model for Lisbon and Porto, Portugal", Computers, Environment and Urban Systems, 26(6): 525-552, doi: 10.1016/S0198-9715(01)00014-X. 3, 1, 17

Sterman, J.D. (2000), Business Dynamics: System Thinking and Modeling for a Complex World, Boston (Irwin/McGraw-Hill). 3

Strauch, D., Moeckel, R., Wegener, M., Gräfe, J., Mühlhans, H., Rindsfüser, G., Beckmann, K.J. (2003), "Linking Transport and Land Use Planning: The Microscopic Dynamic Simulation Model ILUMASS", in Proceedings of the 7th International Conference on GeoComputation, University of Southampton, United Kingdom, 8-10 September 2003, Leeds (University of Leeds). URL (cited on 2 April 2009):

http://www.geocomputation.org/2003/. 3, 1, 9

Living Reviews in Landscape Research

http: //www. livingreviews. org/lrlr-2009-2 
Timmermans, H.J.P. (2006), "The saga of integrated land use and transport modeling: How many more dreams before we wake up?", in Moving Through Nets: The Physical and Social Dimensions of Travel, (Ed.) Axhausen, K.W., Selected papers from the 10th International Conference on Travel Behaviour Research, Lucerne, Switzerland, 10-15 August 2003, pp. 219-248, Oxford (Elsevier). 1.2, 1.3

United Nations (2008), "World Urbanization Prospects: The 2007 Revision", New York (United Nations, Department of Economic and Social Affairs, Population Division). Related online version (cited on 2 April 2009):

http://www.un.org/esa/population/publications/wup2007/2007wup.htm. 1.1

United Nations (2009), "World Population Prospects: The 2008 Revision", New York (United Nations, Department of Economic and Social Affairs, Population Division). Related online version (cited on 2 April 2009):

http://www.un.org/esa/population/publications/wpp2008/. 1.1

U.S. EPA (2000), "Projecting Land-Use Change: A Summary of Models for Assessing the Effects of Community Growth and Change on Land-Use Patterns", EPA/600/R-00/098, Cincinnati, OH (U.S. Environmental Protection Agency, Office of Research and Development). Related online version (cited on 2 April 2009):

http://faculty . washington.edu/pwaddell/Models/REPORTfinal2.pdf. 1.3

Verburg, P.H. (2006), "Simulating feedbacks in land use and land cover change models", Landscape Ecology, 21(8): 1171-1183, doi:10.1007/s10980-006-0029-4. 1.2, 1.4

Verburg, P.H., Overmars, K.P. (2007), "Dynamic Simulation of Land-use change Trajectories with the CLUE-s Model", in Modelling Land-Use Change, Progress and Applications, (Eds.) Koomen, E., Stillwell, J., Bakema, A., Scholten, H.J., pp. 321-335, Dordrecht (Springer), doi:10.1007/9781-4020-5648-2. 3, 1, 6

Verburg, P.H., Schot, P.P., Dijst, M.J., Veldkamp, A. (2004), "Land use change modelling: current practice and research priorities", GeoJournal, 61(4): 309-324, doi:10.1007/s10708-004-4946-y. 1.3

Waddell, P. (2006), "UrbanSim - Status and Further Development", in Integrierte MikroSimulation von Raum- und Verkehrsentwicklung: Theorie, Konzepte, Modelle, Praxis, (Ed.) Beckmann, K.J., Tagungsband des 9. Aachener Kolloquium 'Mobilität und Stadt' (AMUS 2006), 18-19 September 2008, vol. 81 of Schriftenreihe Stadt Region Land, pp. 81-89, Aachen (RWTH). 1,21

Waddell, P., Ulfarsson, G. (2004), "Introduction to urban Simulation: Design and Development of Operational Models", in Handbook of Transport, Geography and Spatial Systems, (Eds.) Stopher, P. Button, K.J., Haynes, K.E., Hensher, D.A., vol. 5 of Handbooks in Transport, pp. 203-236, Amsterdam; Boston (Elsevier). Related online version (cited on 2 April 2009):

http: //www . urbansim.org/papers/waddell-ulfarsson-ht-IntroUrbanSimul.pdf. 1.2

Waddell, P., Borning, A., Noth, M., Freier, N., Becke, M., Ulfarsson, G. (2003), "Microsimulation of Urban Development and Location Choices: Design and Implementation of UrbanSim", Networks and Spatial Economics, 3(1): 43-67, doi:10.1023/A:1022049000877. Related online version (cited on 2 April 2009):

http://www.urbansim.org/papers/UrbanSim_NSE_Paper.pdf. 3, 1, 21 